\title{
Design and synthesis of a novel class of CK2 inhibitors: application of copper- and gold-catalysed cascade reactions for fused nitrogen heterocycles.
}

\section{$\operatorname{AUTHOR}(S)$ :}

Suzuki, Yamato; Oishi, Shinya; Takei, Yoshinori; Yasue, Misato; Misu, Ryosuke; Naoe, Saori; Hou, Zengye; ... Hirasawa, Akira; Tsujimoto, Gozoh; Fujii, Nobutaka

\section{CITATION:}

Suzuki, Yamato ...[et al]. Design and synthesis of a novel class of CK2 inhibitors: application of copper- and gold-catalysed cascade reactions for fused nitrogen heterocycles.. Organic \& biomolecular chemistry 2012, 10(25): 4907-4915

\section{ISSUE DATE:}

2012-04-25

\section{URL:}

http://hdl.handle.net/2433/174130

\section{RIGHT:}

(C) The Royal Society of Chemistry 2012; This is not the published version. Please cite only the published version.; この論文は出版社版で ありません。引用の際には出版社版をご確認ご利用ください。 


\title{
Design and synthesis of novel class of CK2 inhibitors: application of copper- and gold-catalysed cascade reactions for fused nitrogen heterocycles
}

Yamato Suzuki, ${ }^{a}$ Shinya Oishi, ${ }^{* a}$ Yoshinori Takei, ${ }^{a}$ Misato Yasue, ${ }^{a}$ Ryosuke Misu, ${ }^{a}$ Saori Naoe,${ }^{a}$ Zengye Hou, ${ }^{a}$ Tatsuhide Kure ${ }^{b}$ Isao Nakanishi, ${ }^{b}$ Hiroaki Ohno, ${ }^{a}$ Akira Hirasawa, ${ }^{a}$ Gozoh Tsujimoto, ${ }^{a}$ and Nobutaka Fujii*a

${ }^{a}$ Graduate School of Pharmaceutical Sciences, Kyoto University, Sakyo-ku, Kyoto 606-8501, Japan Tel: +81-75-753-4551; Fax: +81-75-753-4570

E-mail: soishi@pharm.kyoto-u.ac.jp; nfujii@pharm.kyoto-u.ac.jp

${ }^{b}$ Faculty of Pharmacy, Kinki University, 3-4-1 Kowakae, Higashi-osaka 577-8502, Japan

\begin{abstract}
Two classes of fused nitrogen heterocycles were designed as CK2 inhibitor candidates on the basis of previous structure-activity relationship (SAR) studies. Various dipyrrolo[3,2-b:2',3'-e]pyridine and benzo[g]indazole derivatives were prepared using transition-metal-catalysed cascade and/or multicomponent reactions. Biological evaluation of these candidates revealed that benzo[g]indazole is a promising scaffold for potent CK2 inhibitors. The inhibitory activities on cell proliferation of these potent CK2 inhibitors are also presented.
\end{abstract}




\section{Introduction}

The protein kinase CK2 (previously called casein kinase II) is a ubiquitous and highly pleiotropic serine/threonine kinase for more than 300 protein substrates. A number of reports have suggested that CK2 is a potential target for cancer treatment because CK2 is overexpressed in a wide variety of tumours, ${ }^{1}$ and various small-molecule CK2 inhibitors have been developed. ${ }^{2}$ CK2 predominantly forms a heterotetramer composed of two catalytic subunits (CK2 $\alpha$ and/or CK2 $\left.\alpha^{\prime}\right)$ and two regulatory subunits $(\mathrm{CK} 2 \beta) .{ }^{3}$ The majority of reported small-molecule CK2 inhibitors target the ATP-binding site of the catalytic subunits. A benzonaphthyridine derivative CX-4945 (1) has been reported as a potent ATP-competitive CK2 inhibitor, and is currently undergoing clinical trials for cancer treatment (Figure 1). ${ }^{4}$

We have also carried out structure-activity relationship (SAR) studies $^{5}$ and crystallographic analyses $^{6}$ of pyrazine-based CK2 inhibitors $2^{5 b}$ (Figure 1) to obtain structural information for the design of novel CK2 inhibitors. These inhibitors 2 bind to CK2 $\alpha$ with a planar horseshoe-shaped conformation to support favourable interactions via van der Waals contacts with hydrophobic residues (Leu45, Val53, Val66, Ile95, Phe113, His160, Met163, and Ile174) in CK2 $\alpha$ as well as hydrogen bonds with the surrounding residues. A nitrogen atom at the 4-position of a pyrazine ring interacts with the backbone NH group of Val116 in the hinge region. The carboxyl group, which is necessary for binding to CK2, interacts by a salt bridge and hydrogen bonds with the Lys68 $\varepsilon$-amino group and the backbone $\mathrm{NH}$ group of Asp175 in the activation loop, and a water molecule in the active site.

We recently identified 2-phenyl-1,3,4-thiadiazoles $\mathbf{3}$ and 3-phenyl-1,2-pyrazole derivatives $\mathbf{4}$ as CK2 inhibitor led by virtual screening of a compound library (Figure 1$){ }^{7}$ Binding mode analysis of the thiadiazole-type inhibitor 3a suggested that unfavourable repulsion exists between one of the thiadiazole nitrogen atoms and the backbone oxygen atom of CK2 $\alpha$-Glu114 (Figure 2A). The pyrazole analogue 4 designed by replacement of the thiadiazole ring in $3 \mathbf{b}\left[\mathrm{IC}_{50}=3.4 \mu \mathrm{M}(\mathrm{CK} 2 \alpha)\right.$ and $\left.1.2 \mu \mathrm{M}\left(\mathrm{CK} 2 \alpha^{\prime}\right)\right]$ with a pyrazole ring would improve the CK2-binding affinity because the NH 
group of the pyrazole could form an additional hydrogen bond with the Glu114 carbonyl oxygen (Figure 2B). The pyrazole-type inhibitor 4 showed more potent inhibitory activity toward CK2 [IC 50 $=0.14 \mu \mathrm{M}(\mathrm{CK} 2 \alpha)$ and $\left.0.063 \mu \mathrm{M}\left(\mathrm{CK} 2 \alpha^{\prime}\right)\right]$ than the thiadiazole $3 \mathbf{b}$ did. Because the other tautomer, 4', may have unfavourable electrostatic repulsions with the binding region (Figure 2B), stabilization of tautomer 4 would enhance the inhibitory activity. In this study, we have designed and synthesized two classes of fused nitrogen heterocycles, using copper- or gold-catalysed cascade reactions. The in vitro inhibitory activities toward two subtypes of the CK2 catalytic subunit (CK2 $\alpha$ and $\left.\mathrm{CK} 2 \alpha^{\prime}\right)$ and anti-proliferative activity of the potent inhibitors are also presented.

\section{Results and discussion}

\section{Design}

On the basis of our previous SAR studies, we designed two fused nitrogen heterocycles $\mathbf{5}$ and $\mathbf{6}$ as novel CK2 inhibitor candidates (Figure 3). The highly fused and rigid scaffold would fix the preferred planar conformation and decrease the entropic loss when incorporated into the binding pocket. ${ }^{6}$ In the dipyrrolo[3,2-b:2', $\left.3^{\prime}-e\right]$ pyridine derivative 5 , a nitrogen atom of the pyridine core and a carboxyl group would form favourable electrostatic interactions with CK2, as the pyrazine-based CK2 inhibitors 2 do (Figure 3A)..$^{5 a, 6}$ The benzo $[g]$ indazole derivatives 6 also have a highly fused and planar structure (Figure 3B). More importantly, in the benzo[g]indazole scaffold (a bridged analogue of the phenylpyrazole 4) the desired tautomer of the pyrazole moiety would be preferred because of the fused benzene ring. ${ }^{8}$ The stabilization effect of this tautomer in $\mathbf{6}$ would enhance the chance of the NH group forming favourable interactions with the Glu114 carbonyl oxygen. Preliminary molecular modelling studies of $\mathbf{6 a}\left(\mathrm{R}^{1}=\mathrm{Ph}, \mathrm{R}^{2}=\mathrm{H}\right)$ using the $\mathrm{CK} 2 \alpha-3 \mathbf{a}$ co-crystal structure suggested that the carboxyl group and two indazole nitrogens could form favourable interactions with CK2 $\alpha$ (Figure 3C).

\section{Synthesis}


We expected that the inhibitor candidates 5 and $\mathbf{6}$ could be synthesized using the transition-metal-catalysed cascade reactions which have been developed by us in recent years. ${ }^{9}$ The synthetic route to dipyrrolo[3,2-b:2',3'-e]pyridine derivatives $5 a-e$ is shown in Scheme 1 . The dipyrrolo[3,2-b:2',3'-e]pyridine framework was constructed using copper-catalysed bis-cyclization of 2,6-diethynylpyridine-3,5-diamine $7 .^{9 a}$ The reaction proceeded smoothly to give 1,7-bismesyldipyrrolo[3,2-b:2',3'-e]pyridine (8). One of the mesyl groups of 8 was selectively removed using $\mathrm{Cs}_{2} \mathrm{CO}_{3}$ and methanol to afford $\mathbf{9}$. The copper-catalysed Ullmann-type coupling of $\mathbf{9}^{10}$ with several aryl or heteroaryl carboxylic acid esters, followed by successive deprotection of a mesyl group and an ester, yielded 1-aryldipyrrolo[3,2-b:2',3'-e]pyridines 5a-e.

Benzo $[g]$ indazole derivatives $6 \mathbf{a}-\mathbf{f}$ were prepared via a gold-catalysed three-component annulation and cyclization cascade ${ }^{9 b}$ as a key step (Scheme 2). 4-Amino-3-bromobenzoic acid (12) was converted to the methyl ester $\mathbf{1 3}$ under acidic conditions. A Sandmeyer reaction using potassium iodide, followed by a Sonogashira coupling with trimethylsilylacetylene (TMS-acetylene) afforded the common intermediate 15. A second Sonogashira coupling with several acetylenes, using tri-tert-butylphosphine as a ligand for palladium, ${ }^{11}$ and removal of the TMS group gave methyl 3,4-diethynylbenzoates 17a-d. A three-component annulation and cyclization cascade of 17 with a hydrazine derivative 18 and aldehydes 19, using a catalytic amount of IPrAuCl [IPr = 1,3-bis(2,6-diisopropylphenyl)imidazol-2-ylidene] and AgOTf, afforded the desired 2,3-dihydrobenzo[g]indazole derivatives 20a-f. The cleavage of a 4-methoxybenzyl (PMB) group and aromatization of a dihydropyrazole ring were achieved by treatment with 2,3-dichloro-5,6-dicyano-1,4-benzoquinone (DDQ) or trifluoroacetic acid (TFA) to give the benzo[g]indazoles 21a-f. Finally, full deprotection of the methyl carbamate and ester yielded the desired compounds $\mathbf{6 a}-\mathbf{f}$.

The 3,4-unsubstituted congener $6 \mathbf{g}\left(\mathrm{R}^{1}\right.$ and $\left.\mathrm{R}^{2}=\mathrm{H}\right)$ was prepared via a different synthetic route (Scheme 3), because of difficulties in using 17 bearing two terminal alkynes $\left(\mathrm{R}^{1}=\mathrm{H}\right)$ for the three-component annulation. The 5-aryl-1-benzylpyrazole derivative $\mathbf{2 6}$ was prepared according to 
the traditional method for construction of pyrazoles from the acetophenone derivative 22. A Sonogashira coupling of $\mathbf{2 6}$ with TMS-acetylene, followed by removal of a TMS group, afforded the cyclization precursor 27. The alkyne 27 was heated with a catalytic amount of IPrAuCl and silver bis(trifluoromethanesulfonyl)imide $\left(\mathrm{AgNTf}_{2}\right)$ to give a benzo[g]indazole derivative $\mathbf{2 1 g}$ via intramolecular hydroarylation of an alkyne, based on our three-component annulation and cyclization cascade. The entire deprotection of the benzyl group ${ }^{12}$ and methyl ester yielded the desired compound 6g.

\section{Evaluation of CK2 inhibitory activity}

The inhibitory activities of the synthesized analogues toward two subtypes of the catalytic subunit of $\mathrm{CK} 2$ (CK2 $\alpha$ and $\left.\mathrm{CK} 2 \alpha^{\prime}\right)$ are summarised in Table 1. Although the dipyrrolo[3,2-b:2',3'-e]pyridine derivative bearing a benzoic acid, 5a, had significantly less potent activity, its pyridine congener $\mathbf{5 b}$ showed moderate activity toward both $\mathrm{CK} 2 \alpha$ and $\mathrm{CK} 2 \alpha^{\prime}\left(\mathrm{IC}_{50}=41\right.$ $\mu \mathrm{M}$ and $26 \mu \mathrm{M}$, respectively). The position of the carboxyl group also had a distinct effect on the activity: the analogue bearing a 4-carboxypyridine moiety, 5c, exhibited higher activity toward $\mathrm{CK} 2 \alpha\left(\mathrm{IC}_{50}=14 \mu \mathrm{M}\right)$ and $\mathrm{CK} 2 \alpha^{\prime}\left(\mathrm{IC}_{50}=12 \mu \mathrm{M}\right)$ than did the 3-, 5-, and 2-substituted analogues 5b, 5d, and 5e.

In contrast, benzo $[g]$ indazole derivatives gave more promising results. The 4-methoxybenzene-substituted analogue $\mathbf{6 b}$ and the thiophene-substituted one $\mathbf{6 d}$ were more potent than the parent pyrazole derivative 4 , despite the loss of the amino group on the pyrazole ring of $\mathbf{4}$, which would form a favourable hydrogen bond with the Val116 carbonyl oxygen (Figure 2B). These results suggest that the benzo[g]indazole core would be a more suitable scaffold for potent CK2 inhibitors than the biaryl-type pyrazoles would be, presumably because of the rigidity of the molecule and/or the predominance of the preferable tautomer of the pyrazole ring. The introduction of an isopropyl group as $\mathrm{R}^{2}$ reduced the binding affinity 100 -fold relative to those of the unsubstituted analogues (compare $\mathbf{6 b}$ with $\mathbf{6 c}$, and $\mathbf{6 d}$ with $\mathbf{6 e}$ ). On the other hand, the absence of a 
substituent at the 4-position $\left(\mathrm{R}^{1}=\mathrm{H}, \mathbf{6 g}\right)$ also lowered the activity relative to those of the other 4-substituted analogues. An aromatic group was preferable to an alkyl chain as the substituent $\mathrm{R}^{1}$, and the electrostatic and/or steric environment of the aromatic ring slightly affected the binding affinity. These observations correspond with the predicted binding affinities of $-23.8,-22.0$, and $-20.7 \mathrm{kcal} / \mathrm{mol}$ for $\mathbf{6 a}, \mathbf{6 f}$, and $\mathbf{6 g}$, respectively.

\section{Evaluation of cytotoxic activity}

Compounds 4, 6b, and $\mathbf{6 d}$, which exerted potent CK2 inhibitory activities, were tested for anti-proliferative effects on colorectal cancer cells, HCT-116 (Figure 4). The cancer cells were treated with increasing concentrations of the compounds, and viabilities were measured by the 3-(4,5-dimethylthiazol-2-yl)-5-(3-carboxymethoxyphenyl)-2-(4-sulfophenyl)-2H-tetrazolium (MTS) assay. The pyrazole 4 had a lower than 50\% inhibitory effect at $100 \mu \mathrm{M}$, whereas the benzo $[g]$ indazoles $\mathbf{6 b}$ and $\mathbf{6 d}$ exhibited moderate inhibitory effects $\left(\mathrm{IC}_{50}=26.5 \mu \mathrm{M}\right.$ and $21.0 \mu \mathrm{M}$, respectively), slightly lower than that of $\mathbf{1}\left(\mathrm{IC}_{50}=6.7 \mu \mathrm{M}\right)$. These data are in linear correlation with the CK2 inhibitory effects.

\section{Conclusion}

In conclusion, we have designed dipyrrolo[3,2-b:2',3'-e]pyridine and benzo[g]indazole derivatives as novel CK2 inhibitor candidates, based on our previous SAR studies. A series of benzo[g]indazole analogues were efficiently prepared using our three-component cascade reaction. Evaluation of the resulting derivatives for CK2 inhibitory activities led to identification of novel potent inhibitors such as the thiophene-substituted benzo $[g]$ indazole derivative $\mathbf{6 d}$. Benzo[ $g]$ indazole is a promising scaffold for highly potent CK2 inhibitors. These results will provide useful information for further studies on CK2 inhibitors with high selectivity toward the two isozymes $\mathrm{CK} 2 \alpha$ and $\mathrm{CK} 2 \alpha^{\prime}$. 


\section{Experimental section}

\section{General}

Melting points were measured by a hot stage melting point apparatus (uncorrected). ${ }^{1} \mathrm{H}$ NMR spectra were recorded using a JEOL AL-400 or JEOL ECA-500 spectrometer, and chemical shifts are reported in $\delta(\mathrm{ppm})$ relative to TMS as internal standard. ${ }^{13} \mathrm{C}$ NMR spectra were recorded using a JEOL AL-400 or JEOL ECA-500 spectrometer and referenced to the residual solvent signal. ${ }^{1} \mathrm{H}$ NMR spectra are tabulated as follows: chemical shift, number of protons, multiplicity $(b=$ broad, $s=$ singlet, $\mathrm{d}=$ doublet, $\mathrm{t}=$ triplet, $\mathrm{q}=$ quartet, $\mathrm{m}=$ multiplet $)$, and coupling constant( $\mathrm{s})$. Exact mass (HRMS) spectra were recorded on a JMS-HX/HX 110A mass spectrometer. Infrared (IR) spectra were obtained on a JASCO FT/IR-4100 FT-IR spectrometer with JASCO ATR PRO410-S. Compounds $7,{ }^{9 a} \mathbf{8},{ }^{9 a}$ and $22^{13}$ were prepared according to the literatures.

1-(Methylsulfonyl)-1,7-dihydrodipyrrolo[3,2-b:2',3'-e]pyridine (9). To the mixture of 8 (700 mg, $2.23 \mathrm{mmol})$ in $\mathrm{MeOH} / \mathrm{THF}\left(1: 1,220 \mathrm{~cm}^{3}\right)$ was added $\mathrm{Cs}_{2} \mathrm{CO}_{3}(2.18 \mathrm{~g}, 6.70 \mathrm{mmol})$. After stirring at $\mathrm{rt}$ for $12 \mathrm{~h}, \mathrm{NH}_{4} \mathrm{Cl}(835 \mathrm{mg}, 15.6 \mathrm{mmol})$ was added and the mixture was stirred at $\mathrm{rt}$ for 1.5 h. It was concentrated in vacuo and the residue was diluted with $\mathrm{CHCl}_{3}$. After filtration, the mixture was concentrated and the residue was chromatographed on silica gel $\left(\mathrm{CHCl}_{3} / \mathrm{MeOH}=10 / 1\right)$ to afford the title compound 9 (407 $\mathrm{mg}, 78 \%$ ) as a white solid: $\mathrm{mp} 218-219{ }^{\circ} \mathrm{C}$ (decomp); $\delta_{\mathrm{H}}(400 \mathrm{MHz}$; $\left.\mathrm{CDCl}_{3} ; \mathrm{Me}_{4} \mathrm{Si}\right) 3.05(3 \mathrm{H}, \mathrm{s}), 6.80-6.82(1 \mathrm{H}, \mathrm{m}), 6.97(1 \mathrm{H}, \mathrm{dd}, J 3.8,0.6 \mathrm{~Hz}), 7.57-7.59(1 \mathrm{H}, \mathrm{m})$, $7.65(1 \mathrm{H}, \mathrm{d}, J 3.8 \mathrm{~Hz}), 8.25\left(1 \mathrm{H}\right.$, br s), and $8.46(1 \mathrm{H}, \mathrm{s}) ; \delta \mathrm{c}\left(100 \mathrm{MHz} ; \mathrm{CDCl}_{3}\right) 40.2,103.1,103.1$, 110.7, 127.0, 128.8, 129.5, 131.3, 145.4, and 145.7. Anal. Found: C, 52.0; H, 3.9; N, 17.9. Calc. for $\mathrm{C}_{10} \mathrm{H}_{9} \mathrm{~N}_{3} \mathrm{O}_{2} \mathrm{~S}: \mathrm{C}, 52.0 ; \mathrm{H}, 3.8 ; \mathrm{N}, 17.6 \%$.

Representative procedure for coupling reactions of 9 with aryl halides 10a-e: synthesis of ethyl 4-\{7-(Methylsulfonyl)dipyrrolo[3,2-b:2',3'-e]pyridin-1(7H)-yl\}benzoate (11a). Under argon atmosphere, the mixture of 9 (50 mg, $0.21 \mathrm{mmol})$, ethyl 4-iodobenzoate (10a) (70 $\mathrm{mg}, 0.26 \mathrm{mmol})$, 
CuI (4 mg, $0.021 \mathrm{mmol}),( \pm)$-trans- $N, N^{\prime}$-dimethylcyclohexane-1,2-diamine A $\left(0.007 \mathrm{~cm}^{3}, 0.042\right.$ $\mathrm{mmol})$, and $\mathrm{K}_{3} \mathrm{PO}_{4}(113 \mathrm{mg}, 0.53 \mathrm{mmol})$ in 1,4-dioxane $\left(1 \mathrm{~cm}^{3}\right)$ was refluxed for $3 \mathrm{~h}$. The mixture was diluted with EtOAc and filtered. The filtrate was concentrated and chromatographed on silica gel (hexane/EtOAc $=1 / 1)$ to afford the title compound $11 \mathrm{a}(73 \mathrm{mg}, 90 \%)$ as a white solid: $\mathrm{mp} 75-76^{\circ} \mathrm{C}$; IR (neat): $v_{\max } / \mathrm{cm}^{-1} 1698(\mathrm{C}=\mathrm{O}), 1278\left(\mathrm{OCH}_{3}\right) ; \delta_{\mathrm{H}}\left(400 \mathrm{MHz} ; \mathrm{CDCl}_{3} ; \mathrm{Me} 4 \mathrm{Si}\right) 1.44(3 \mathrm{H}, \mathrm{t}, J 7.1 \mathrm{~Hz})$, $3.06(3 \mathrm{H}, \mathrm{s}), 4.43(2 \mathrm{H}, \mathrm{q}, J 7.1 \mathrm{~Hz}), 6.96(1 \mathrm{H}, \mathrm{d}, J 3.7 \mathrm{~Hz}), 6.98(1 \mathrm{H}, \mathrm{d}, J 3.7 \mathrm{~Hz}), 7.58-7.61(2 \mathrm{H}, \mathrm{m})$, $7.68(1 \mathrm{H}, \mathrm{d}, J 3.7 \mathrm{~Hz}), 7.72(1 \mathrm{H}, \mathrm{d}, J 3.7 \mathrm{~Hz}), 8.24-8.27(2 \mathrm{H}, \mathrm{m})$, and $8.40(1 \mathrm{H}, \mathrm{s}) ; \delta_{\mathrm{C}}(100 \mathrm{MHz}$; $\left.\mathrm{CDCl}_{3}\right) 14.3,40.4,61.2,102.5,105.0,110.3,123.1(2 \mathrm{C}), 126.0,127.0,128.7,129.4,131.5(2 \mathrm{C})$, 132.1, 142.6, 145.8, 146.9, and 165.6; HRMS (FAB) $\mathrm{m} / z$ Calc. for $\mathrm{C}_{19} \mathrm{H}_{18} \mathrm{~N}_{3} \mathrm{O}_{4} \mathrm{~S}\left(\mathrm{MH}^{+}\right)$384.1013, found 384.1014 .

\section{Representative procedure for removal of protecting groups of 11a-e: Synthesis of} 4-\{dipyrrolo[3,2-b:2',3'-e]pyridin-1(7H)-yl\}benzoic acid (5a). To the mixture of 11a (60 mg, 0.16 $\mathrm{mmol})$ in $\mathrm{MeOH} / \mathrm{THF}\left(1: 1,16 \mathrm{~cm}^{3}\right)$ was added $\mathrm{Cs}_{2} \mathrm{CO}_{3}(153 \mathrm{mg}, 0.47 \mathrm{mmol})$. After stirring at $\mathrm{rt}$ for $12 \mathrm{~h}$, the mixture was concentrated in vacuo. The residue was diluted with sat. aqueous $\mathrm{NH}_{4} \mathrm{Cl}$ and the mixture was extracted with EtOAc twice. The combined extracts were washed with brine, dried over $\mathrm{Na}_{2} \mathrm{SO}_{4}$, and concentrated in vacuo. The crude product was dissolved with THF $\left(3 \mathrm{~cm}^{3}\right)$ and $3 \mathrm{~N}$ $\mathrm{NaOH}\left(0.3 \mathrm{~cm}^{3}\right)$ was added. The mixture was stirred at $\mathrm{rt}$ for $40 \mathrm{~h}$ and concentrated in vacuo. The residue was dissolved in water $\left(c a .1 \mathrm{~cm}^{3}\right)$ and filtered. The filtrate was acidified with $3 \mathrm{~N} \mathrm{HCl}$, then $28 \%$ aqueous $\mathrm{NH}_{3}$ was added until the mixture was clear solution. The solution was freeze dried and the residue was purified by reverse phase HPLC [3-6\% $\mathrm{MeCN}$ in $\mathrm{H}_{2} \mathrm{O}$ (containing $0.1 \% \mathrm{NH}_{3}$ ); flow rate: $10 \mathrm{~cm}^{3} \mathrm{~min}^{-1}$ ] to afford the title compound $\mathbf{5 a}$ as an $\mathrm{NH}_{3}$ salt $(24.9 \mathrm{mg}, 54 \%)$. Pale yellow solid: $\mathrm{mp}>300{ }^{\circ} \mathrm{C}$; IR (neat): $v_{\max } / \mathrm{cm}^{-1} 1602(\mathrm{C}=\mathrm{O}) ; \delta_{\mathrm{H}}\left(500 \mathrm{MHz} ; \mathrm{DMSO}-d_{6} ; \mathrm{Me}_{4} \mathrm{Si}\right) 6.55-6.57(1 \mathrm{H}, \mathrm{br}$ m), $6.82(1 \mathrm{H}, \mathrm{d}, J 3.4 \mathrm{~Hz}), 7.65-7.67(1 \mathrm{H}, \mathrm{m}), 7.81(2 \mathrm{H}, \mathrm{d}, J 8.0 \mathrm{~Hz}), 7.98(1 \mathrm{H}, \mathrm{d}, J 3.4 \mathrm{~Hz}), 8.05$ $(1 \mathrm{H}, \mathrm{s}), 8.16(2 \mathrm{H}, \mathrm{d}, J 8.0 \mathrm{~Hz})$, and $11.03(1 \mathrm{H}, \mathrm{s}) ; \delta_{\mathrm{C}}(125 \mathrm{MHz}$; DMSO-d6) 99.7, 100.4, 104.5, 122.3 (2C), 125.5, 126.6, 128.0, 129.6, 130.5, 131.1 (2C), 142.8, 144.3, 144.4, and 166.8; HRMS (FAB) 
$m / z$ Calc. for $\mathrm{C}_{16} \mathrm{H}_{10} \mathrm{~N}_{3} \mathrm{O}_{2}[\mathrm{M}-\mathrm{H}]^{-} 276.0779$, found 276.0781 .

Methyl 4-amino-3-bromobenzoate (13). To the mixture of 4-amino-3-bromobenzoic acid 12 (5.4 $\mathrm{g}, 25 \mathrm{mmol})$ in $\mathrm{MeOH}\left(30 \mathrm{~cm}^{3}\right)$ was added sulphuric acid $\left(0.83 \mathrm{~cm}^{3}\right)$, then the mixture was refluxed for $20 \mathrm{~h}$. The mixture was cooled to $0{ }^{\circ} \mathrm{C}$ and basified with sat. aqueous $\mathrm{NaHCO}_{3}(\mathrm{ca} .100$ $\mathrm{cm}^{3}$ ). The precipitates were collected and washed with water. Recrystallization from $\mathrm{MeOH}-\mathrm{H}_{2} \mathrm{O}$ afforded the title compound $13(5.34 \mathrm{~g}, 93 \%)$ as a white solid. All spectral data were in good agreement with those reported by Bräse et al. ${ }^{14}$

Methyl 3-bromo-4-iodobenzoate (14). To the stirred suspension of 13 (5.0 g, $21.7 \mathrm{mmol})$ in $6 \mathrm{~N} \mathrm{HCl}\left(40 \mathrm{~cm}^{3}\right)$ was added a solution of $\mathrm{NaNO}_{2}(3.0 \mathrm{~g}, 43.4 \mathrm{mmol})$ in $\mathrm{H}_{2} \mathrm{O}\left(20 \mathrm{~cm}^{3}\right)$ dropwise over $15 \mathrm{~min}$ at $0{ }^{\circ} \mathrm{C}$. After stirring at $0{ }^{\circ} \mathrm{C}$ for $1 \mathrm{~h}$, a solution of $\mathrm{KI}(5.4 \mathrm{~g}, 32.6 \mathrm{mmol})$ in $\mathrm{H}_{2} \mathrm{O}\left(16 \mathrm{~cm}^{3}\right)$ was added dropwise to the reaction mixture over $15 \mathrm{~min}$ at $0{ }^{\circ} \mathrm{C}$. The mixture was vigorously stirred at $\mathrm{rt}$ for $24 \mathrm{~h}$ in the dark. The precipitate was collected and washed with $\mathrm{H}_{2} \mathrm{O}$. The solid was dissolved in $\mathrm{Et}_{2} \mathrm{O}$, then the mixture was washed with aqueous $\mathrm{Na}_{2} \mathrm{~S}_{2} \mathrm{O}_{3}, \mathrm{H}_{2} \mathrm{O}$, and brine, dried over $\mathrm{MgSO}_{4}$, and concentrated in vacuo. The residue was filtered through a silica gel pad with elution of hexane/EtOAc (50/1). The filtrate was concentrated and recrystallized from hot hexane to afford the title compound 14 (3.9 g, 53\%) as colourless crystals. All spectral data were in good agreement with those reported. $^{15}$

Methyl 3-bromo-4-[(trimethylsilyl)ethynyl]benzoate (15). Under argon atmosphere, Et $3 \mathrm{~N}$ $\left(7.3 \mathrm{~cm}^{3}, 53 \mathrm{mmol}\right)$ and TMS-acetylene $\left(1.8 \mathrm{~cm}^{3}, 12.7 \mathrm{mmol}\right)$ were added to the mixture of $14(3.6 \mathrm{~g}$, $10.6 \mathrm{mmol}), \mathrm{PdCl}_{2}\left(\mathrm{PPh}_{3}\right)_{2}(190 \mathrm{mg}, 0.27 \mathrm{mmol})$ and $\mathrm{CuI}(50 \mathrm{mg}, 0.27 \mathrm{mmol})$ in THF $\left(35 \mathrm{~cm}^{3}\right)$, then the mixture was stirred at $\mathrm{rt}$ for $12 \mathrm{~h}$. The mixture was concentrated in vacuo and the residue was diluted with $\mathrm{Et}_{2} \mathrm{O}$ and filtered through a silica gel pad. The filtrate was concentrated in vacuo and the residue was chromatographed on silica gel (hexane/EtOAc $=20 / 1)$ to afford the title compound 15 
$(3.19 \mathrm{~g}, 97 \%)$ as a yellow oil. All spectral data were in good agreement with those reported. ${ }^{16}$

\section{Representative procedure for coupling reactions of 15 with 16a-d and removal of a TMS}

group: Synthesis of methyl 4-ethynyl-3-(thiophen-2-ylethynyl)benzoate (17c). Under argon atmosphere, $15(938 \mathrm{mg}, 3.01 \mathrm{mmol})$ was dissolved in toluene $\left(3 \mathrm{~cm}^{3}\right)$. To the solution were added $\mathrm{PdCl}_{2}(\mathrm{PhCN})_{2}(35 \mathrm{mg}, 0.09 \mathrm{mmol}), \mathrm{CuI}(11 \mathrm{mg}, 0.06 \mathrm{mmol}), i-\mathrm{Pr}_{2} \mathrm{NH}\left(1.3 \mathrm{~cm}^{3}, 9.03 \mathrm{mmol}\right)$, 2-ethynylthiophene $(\mathbf{1 6 c}),{ }^{17}$ and a solution of $t$ - $\mathrm{Bu}_{3} \mathrm{P}$ in toluene $\left(1.0 \mathrm{M}, 0.18 \mathrm{~cm}^{3}\right)$ and the mixture was stirred at $\mathrm{rt}$ for $7 \mathrm{~h}$. The resulting mixture was filtered through a silica gel pad with elution of hexane/EtOAc (9/1). The filtrate was concentrated in vacuo and chromatographed on silica gel (hexane/EtOAc $=9 / 1)$ to afford methyl 3-(thiophen-2-ylethynyl)-4-[(trimethylsilyl)ethynyl]benzoate

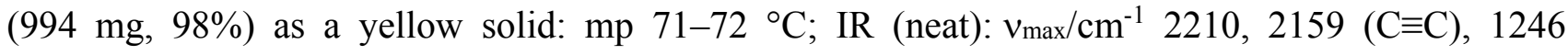
$\left(\mathrm{OCH}_{3}\right) ; \delta_{\mathrm{H}}\left(400 \mathrm{MHz} ; \mathrm{CDCl}_{3} ; \mathrm{Me} 4 \mathrm{Si}\right) 0.29(9 \mathrm{H}, \mathrm{s}), 3.92(3 \mathrm{H}, \mathrm{s}), 7.03(1 \mathrm{H}, \mathrm{dd}, J$ 5.1, $3.7 \mathrm{~Hz})$, $7.31-7.33(2 \mathrm{H}, \mathrm{m}), 7.54(1 \mathrm{H}, \mathrm{d}, J 8.2 \mathrm{~Hz}), 7.90(1 \mathrm{H}, \mathrm{dd}, J 8.2,1.7 \mathrm{~Hz})$, and $8.16(1 \mathrm{H}, \mathrm{d}, J 1.7 \mathrm{~Hz}) ; \delta \mathrm{c}$ $\left(100 \mathrm{MHz} ; \mathrm{CDCl}_{3}\right)$ 52.5, 87.5, 91.2, 102.5, 102.6, 123.0, 126.3, 127.3, 128.1, 128.7, 129.5, 129.8, 132.3, 132.5, 132.7, and 166.0; HRMS (FAB) $m / z$ Calc. for $\mathrm{C}_{19} \mathrm{H}_{19} \mathrm{O}_{2} \mathrm{SSi}\left(\mathrm{MH}^{+}\right)$339.0870, found 339.0874 .

The coupling product (475 mg, $1.40 \mathrm{mmol})$ was dissolved in $\mathrm{MeOH}\left(14 \mathrm{~cm}^{3}\right)$. After addition of $\mathrm{K}_{2} \mathrm{CO}_{3}(388 \mathrm{mg}, 2.80 \mathrm{mmol}$ ), the mixture was stirred at $\mathrm{rt}$ for $1 \mathrm{~h}$. The resulting mixture was acidified with sat. aqueous citric acid and extracted with $\mathrm{Et}_{2} \mathrm{O}$. The extract was washed with $\mathrm{H}_{2} \mathrm{O}$ and brine, dried over $\mathrm{MgSO}_{4}$, and concentrated in vacuo. The residue was chromatographed on silica gel (hexane/EtOAc $=9 / 1)$ followed by recrystallization from $\mathrm{CHCl}_{3}$-hexane to afford the title compound 17c $(259 \mathrm{mg}, 70 \%)$ as pale yellow crystals: $\mathrm{mp} 75-76^{\circ} \mathrm{C}$; IR (neat): $v_{\max } / \mathrm{cm}^{-1} 3246(\mathrm{C} \equiv \mathrm{CH}), 2195$ $(\mathrm{C} \equiv \mathrm{C}), 1717(\mathrm{C}=\mathrm{O}), 1244\left(\mathrm{OCH}_{3}\right) ; \delta_{\mathrm{H}}\left(500 \mathrm{MHz} ; \mathrm{CDCl}_{3} ; \mathrm{Me}_{4} \mathrm{Si}\right) 3.51(1 \mathrm{H}, \mathrm{s}), 3.93(3 \mathrm{H}, \mathrm{s})$, 7.02-7.04 (1H, m), $7.33(1 \mathrm{H}, \mathrm{s}), 7.34-7.35(1 \mathrm{H}, \mathrm{m}), 7.58(1 \mathrm{H}, \mathrm{d}, J 8.0 \mathrm{~Hz}), 7.93(1 \mathrm{H}, \mathrm{dd}, J$ 8.0, 1.7 $\mathrm{Hz})$, and $8.18(1 \mathrm{H}, \mathrm{d}, J 1.7 \mathrm{~Hz}) ; \delta_{\mathrm{C}}\left(125 \mathrm{MHz} ; \mathrm{CDCl}_{3}\right) 52.4,81.4,84.1,87.6,90.7,126.4,127.2$, 128.1, 128.4, 128.7, 130.1, 132.6, 132.6 (2C), and 165.8. Anal. Found: C, 72.4; H, 4.0. Calc. for 
$\mathrm{C}_{16} \mathrm{H}_{10} \mathrm{O}_{2} \mathrm{~S}: \mathrm{C}, 72.2 ; \mathrm{H}, 3.8 \%$.

Methyl 2-(4-methoxybenzyl)hydrazinecarboxylate (18). The mixture of methyl hydrazinecarboxylate $(10.0 \mathrm{~g}, 111 \mathrm{mmol})$ and $p$-anisaldehyde $\left(15 \mathrm{~cm}^{3}, 122 \mathrm{mmol}\right)$ in $\mathrm{Et}_{2} \mathrm{O}\left(400 \mathrm{~cm}^{3}\right)$ was stirred at $35{ }^{\circ} \mathrm{C}$ for $15 \mathrm{~h}$. The reaction mixture was concentrated in vacuo until $\mathrm{ca} .50 \mathrm{~cm}^{3}$ and the residue was diluted with toluene. The precipitate was collected and washed with hexane to afford methyl 2-(4-methoxybenzylidene)hydrazinecarboxylate $(20.3 \mathrm{~g}, 88 \%)$ as a white solid: $\mathrm{mp}$ 123-124 ${ }^{\circ} \mathrm{C}$; IR (neat): $v_{\max } / \mathrm{cm}^{-1} 3252(\mathrm{NH}), 1712(\mathrm{C}=\mathrm{O}), 1249\left(\mathrm{OCH}_{3}\right) ; \delta_{\mathrm{H}}\left(400 \mathrm{MHz} ; \mathrm{CDCl}_{3}\right.$; Me $4 \mathrm{Si}) 3.84(3 \mathrm{H}, \mathrm{s}), 3.85(3 \mathrm{H}, \mathrm{br} \mathrm{s}), 6.90(2 \mathrm{H}, \mathrm{d}, J 8.8 \mathrm{~Hz}), 7.63(2 \mathrm{H}, \mathrm{d}, J 8.8 \mathrm{~Hz}), 7.79(1 \mathrm{H}$, br s), and $7.90(1 \mathrm{H}, \mathrm{s}) ; \delta_{\mathrm{C}}\left(100 \mathrm{MHz} ; \mathrm{CDCl}_{3}\right) 52.7,55.2,113.9(2 \mathrm{C}), 126.4,128.7(2 \mathrm{C}), 144.8,154.6$, and 161.0. Anal. Found: C, 57.6; H, 5.6; N, 13.6. Calc. for $\mathrm{C}_{10} \mathrm{H}_{12} \mathrm{~N}_{2} \mathrm{O}_{3}$ : C, 57.7; H, 5.8; N, 13.5\%.

The mixture of benzylidenehydrazine $(5.0 \mathrm{~g}, 24.0 \mathrm{mmol})$ and $10 \% \mathrm{Pd} / \mathrm{C}(2.5 \mathrm{~g})$ in $\mathrm{EtOH}(340$ $\mathrm{cm}^{3}$ ) was stirred under hydrogen atmosphere at $\mathrm{rt}$ for $1.5 \mathrm{~h}$. The reaction mixture was filtered through Celite and concentrated. The residue was chromatographed on silica gel (hexane/EtOAc $=2 / 3$ ) followed by recrystallization from hexane to afford the title compound $\mathbf{1 8}(3.56 \mathrm{~g}, 71 \%)$ as colourless crystals: $\mathrm{mp} 63-64{ }^{\circ} \mathrm{C}$; IR (neat): $v_{\max } / \mathrm{cm}^{-1} 3301(\mathrm{NH}), 1684(\mathrm{C}=\mathrm{O}), 1251\left(\mathrm{OCH}_{3}\right) ; \delta_{\mathrm{H}}$ (400 MHz; $\left.\mathrm{CDCl}_{3} ; \mathrm{Me}_{4} \mathrm{Si}\right) 3.73$ (3H, br s), 3.80 (3H, s), $3.94(2 \mathrm{H}, \mathrm{d}, J 4.9 \mathrm{~Hz}), 4.15$ (1H, br s), 6.15 $\left(1 \mathrm{H}\right.$, br s), 6.86-6.88 $(2 \mathrm{H}, \mathrm{m})$, and 7.25-7.27 (3H, m); $\delta_{\mathrm{C}}\left(100 \mathrm{MHz} ; \mathrm{CDCl}_{3}\right) 52.3,55.1,55.2,113.8$ (2C), 129.4, 130.1 (2C), 157.8, and 159.0. Anal. Found: C, 57.3; H, 6.5; N, 13.4. Calc. for $\mathrm{C}_{10} \mathrm{H}_{14} \mathrm{~N}_{2} \mathrm{O}_{3}: \mathrm{C}, 57.1 ; \mathrm{H}, 6.7 ; \mathrm{N}, 13.3 \%$.

Representative procedure for gold-catalysed three-component annulation and cyclisation cascade reactions of $17 a-d$ with 18 and 19a,b: Synthesis of dimethyl 2-(4-methoxybenzyl)-4-(4-methoxyphenyl)-2,3-dihydro-1H-benzo[g]indazole-1,7-dicarboxylate (20b). Under argon atmosphere, the mixture of $\mathbf{1 7 b}(20 \mathrm{mg}, 0.069 \mathrm{mmol})$, a hydrazine 18 (5.8 $\mathrm{mg}$, $0.028 \mathrm{mmol})$, paraformaldehyde 19a $(1.7 \mathrm{mg}, 0.055 \mathrm{mmol}$ as $\mathrm{HCHO}), \operatorname{IPrAuCl}(2.1 \mathrm{mg}, 3.5 \mu \mathrm{mol})$, 
and $\operatorname{AgOTf}(0.9 \mathrm{mg}, 3.5 \mu \mathrm{mol})$ in $\mathrm{AcOH}\left(0.35 \mathrm{~cm}^{3}\right)$ was stirred at $35^{\circ} \mathrm{C}$ for $2 \mathrm{~h}$, then the additional hydrazine 18 (5.8 mg, $0.028 \mathrm{mmol})$ and paraformaldehyde 19a (1.7 $\mathrm{mg}, 0.055 \mathrm{mmol}$ as $\mathrm{HCHO})$ were added. After stirred at $35{ }^{\circ} \mathrm{C}$ for $2 \mathrm{~h}$, further hydrazine 18 (5.8 $\left.\mathrm{mg}, 0.028 \mathrm{mmol}\right)$ and paraformaldehyde 19a $(1.7 \mathrm{mg}, 0.055 \mathrm{mmol}$ as $\mathrm{HCHO})$ were added and stirred for $2 \mathrm{~h}$. The reaction mixture was poured into sat. aqueous $\mathrm{NaHCO}_{3}$ and the mixture was extracted with EtOAc twice. The combined extracts were washed with $\mathrm{H}_{2} \mathrm{O}$ and brine, dried over $\mathrm{Na}_{2} \mathrm{SO}_{4}$, and concentrated in vacuo. The residue was chromatographed on silica gel (hexane/EtOAc $=10 / 1$ to $2 / 1$ ) to afford the title compound 20b [11.5 mg, 33\% (41\% rsm)] as a yellow oil: IR (neat): $v_{\max } / \mathrm{cm}^{-1} 1716,1609(\mathrm{C}=\mathrm{O})$, $1251\left(\mathrm{OCH}_{3}\right) ; \delta_{\mathrm{H}}\left(500 \mathrm{MHz} ; \mathrm{CDCl}_{3} ; \mathrm{Me}_{4} \mathrm{Si}, 50^{\circ} \mathrm{C}\right) 3.75(3 \mathrm{H}, \mathrm{s}), 3.79(2 \mathrm{H}, \mathrm{br} \mathrm{s}), 3.79(3 \mathrm{H}, \mathrm{s}), 3.86$ $(3 \mathrm{H}, \mathrm{s}), 3.99(3 \mathrm{H}, \mathrm{s}), 4.34(2 \mathrm{H}, \mathrm{br} \mathrm{s}), 6.76(2 \mathrm{H}, \mathrm{d}, J 8.6 \mathrm{~Hz}), 7.00(2 \mathrm{H}, \mathrm{d}, J 8.6 \mathrm{~Hz}), 7.19(2 \mathrm{H}, \mathrm{d}, J 8.6$ $\mathrm{Hz}), 7.37(2 \mathrm{H}, \mathrm{d}, J 8.6 \mathrm{~Hz}), 7.81(1 \mathrm{H}, \mathrm{s}), 8.01-8.07(2 \mathrm{H}, \mathrm{m})$, and $8.63(1 \mathrm{H}, \mathrm{s}) ; \delta_{\mathrm{C}}\left(100 \mathrm{MHz} ; \mathrm{CDCl}_{3}\right)$ $52.3,53.6,55.2,55.4,57.7,61.7,113.5(2 \mathrm{C}), 114.4(2 \mathrm{C}), 124.8,125.6,125.8,127.2,127.5,128.3$, 129.2 (2C), 130.1, 131.1 (2C), 131.2, 131.5, 133.6, 136.2, 137.3, 157.0, 159.1, 159.5, and 167.1; HRMS (FAB) $m / z$ Calc. for $\mathrm{C}_{30} \mathrm{H}_{29} \mathrm{~N}_{2} \mathrm{O}_{6}\left(\mathrm{MH}^{+}\right)$513.2020, found 513.2011.

\section{Dimethyl 3-isopropyl-2-(4-methoxybenzyl)-4-(thiophen-2-yl)-2,3-dihydro-1H-benzo[g]-} indazole-1,7-dicarboxylate (20e). Under argon atmosphere, the mixture of 17c (40 mg, $0.15 \mathrm{mmol})$, a hydrazine 18 (35 mg, $0.17 \mathrm{mmol})$, isobutyraldehyde $19 b\left(0.027 \mathrm{~cm}^{3}, 0.30 \mathrm{mmol}\right), \operatorname{IPrAuCl}(4.7 \mathrm{mg}$, $7.5 \mu \mathrm{mol})$, and AgOTf $(1.9 \mathrm{mg}, 7.5 \mu \mathrm{mol})$ in $\mathrm{AcOH}\left(1.5 \mathrm{~cm}^{3}\right)$ was stirred at $50{ }^{\circ} \mathrm{C}$ for $7 \mathrm{~h}$. The reaction mixture was poured into sat. aqueous $\mathrm{NaHCO}_{3}$ and the mixture was extracted with EtOAc twice. The combined extracts were washed with $\mathrm{H}_{2} \mathrm{O}$ and brine, dried over $\mathrm{Na}_{2} \mathrm{SO}_{4}$, and concentrated in vacuo. The residue was chromatographed on silica gel (hexane/EtOAc $=4 / 1$ ) to afford the title compound 20e $(67.6 \mathrm{mg}, 85 \%)$ as a yellow oil: IR (neat): $v_{\max } / \mathrm{cm}^{-1} 1717,1612(\mathrm{C}=\mathrm{O}) ; \delta_{\mathrm{H}}(400$ $\left.\mathrm{MHz} ; \mathrm{CDCl}_{3} ; \mathrm{Me}_{4} \mathrm{Si}\right) 0.53(3 \mathrm{H}, \mathrm{d}, J 6.8 \mathrm{~Hz}), 0.61(3 \mathrm{H}, \mathrm{d}, J 6.8 \mathrm{~Hz}), 1.55-1.63(1 \mathrm{H}, \mathrm{m}), 3.77(1 \mathrm{H}, \mathrm{d}$, $J 12.2 \mathrm{~Hz}), 3.79(3 \mathrm{H}, \mathrm{s}), 3.86(3 \mathrm{H}, \mathrm{s}), 3.99(3 \mathrm{H}, \mathrm{s}), 4.12(1 \mathrm{H}, \mathrm{d}, J 12.2 \mathrm{~Hz}), 4.36(1 \mathrm{H}, \mathrm{d}, J 3.4 \mathrm{~Hz})$, $6.84(2 \mathrm{H}, \mathrm{d}, J 8.5 \mathrm{~Hz}), 7.11(1 \mathrm{H}, \mathrm{dd}, J 4.8,3.4 \mathrm{~Hz}), 7.21(1 \mathrm{H}, \mathrm{d}, J 3.7 \mathrm{~Hz}), 7.34-7.38(3 \mathrm{H}, \mathrm{m}), 7.90$ 
$(1 \mathrm{H}, \mathrm{s}), 8.00-8.07(2 \mathrm{H}, \mathrm{m})$, and $8.61(1 \mathrm{H}, \mathrm{s}) ; \delta_{\mathrm{C}}\left(100 \mathrm{MHz} ; \mathrm{CDCl}_{3}\right) 16.0,20.1,30.9,52.2,53.3,55.2$, $62.6,72.4,113.4$ (s, 2H), 124.9, 125.5, 125.7, 125.9, 126.0, 127.6, 127.7, 127.8, 128.5, 129.6, 131.1, 131.2, $131.6(\mathrm{~s}, 2 \mathrm{H}), 133.6,137.6,141.3,157.1,159.2$, and 167.0; HRMS (FAB) $m / z$ Calc. for $\mathrm{C}_{30} \mathrm{H}_{31} \mathrm{~N}_{2} \mathrm{O}_{5} \mathrm{~S}\left(\mathrm{MH}^{+}\right)$531.1948, found 531.1946.

\section{Deprotection and aromatisation of 20: 4-Phenyl-1H-benzo[g]indazole-7-carboxylic acid}

(6a). Compound 20a $(20 \mathrm{mg}, 0.042 \mathrm{mmol})$ and anisole $\left(0.022 \mathrm{~cm}^{3}, 0.21 \mathrm{mmol}\right)$ were dissolved in TFA $\left(0.6 \mathrm{~cm}^{3}\right)$. After stirring at $80{ }^{\circ} \mathrm{C}$ for $12 \mathrm{~h}$, the mixture was poured into sat. aqueous $\mathrm{NaHCO}_{3}$ and the mixture was extracted with EtOAc twice. The combined extracts were washed with $\mathrm{H}_{2} \mathrm{O}$ and brine, dried over $\mathrm{Na}_{2} \mathrm{SO}_{4}$, and concentrated in vacuo. The crude product (21a) was dissolved in 1,4-dioxane $\left(0.4 \mathrm{~cm}^{3}\right)$, then $3 \mathrm{~N} \mathrm{NaOH}\left(0.083 \mathrm{~cm}^{3}, 0.25 \mathrm{mmol}\right)$ was added. After stirring at $40{ }^{\circ} \mathrm{C}$ for $12 \mathrm{~h}, \mathrm{NH}_{4} \mathrm{Cl}(22 \mathrm{mg}, 0.42 \mathrm{mmol}$ ) was added and the mixture was stirred at $\mathrm{rt}$ for $1 \mathrm{~h}$. The mixture was concentrated in vacuo and the residue was chromatographed on silica gel $\left(\mathrm{CHCl}_{3} / \mathrm{MeOH}=9 / 1\right)$ to afford the title compound $\mathbf{6 a}(5.8 \mathrm{mg}, 49 \%)$ as a white solid: $\mathrm{mp}>300{ }^{\circ} \mathrm{C}$; IR (neat): $v_{\max } / \mathrm{cm}^{-1}$ $1703(\mathrm{C}=\mathrm{O}) ; \delta_{\mathrm{H}}\left(500 \mathrm{MHz}\right.$; DMSO- $\left.d_{6} ; \mathrm{Me}_{4} \mathrm{Si}\right) 7.48(1 \mathrm{H}, \mathrm{dd}, J$ 7.6, 7.6 Hz), $7.58(2 \mathrm{H}, \mathrm{dd}, J$ 7.6, 7.6 Hz), $7.78(1 \mathrm{H}, \mathrm{s}), 7.85(2 \mathrm{H}, \mathrm{d}, J 7.6 \mathrm{~Hz}), 8.17(1 \mathrm{H}, \mathrm{d}, J 8.6 \mathrm{~Hz}), 8.28(1 \mathrm{H}, \mathrm{s}), 8.53(1 \mathrm{H}, \mathrm{d}, J 8.6 \mathrm{~Hz})$, and $8.70(1 \mathrm{H}, \mathrm{s}) ; \delta_{\mathrm{C}}\left(125 \mathrm{MHz}\right.$; DMSO- $\left.d_{6}\right) 118.7,121.0,121.6(2 \mathrm{C}), 123.3,126.49,126.53,127.9$, 128.2 (2C), 129.0 (2C), 130.4, 131.4, 131.7, 133.0, 139.1, and 167.8; HRMS (FAB) $m / z$ Calc. for $\mathrm{C}_{18} \mathrm{H}_{11} \mathrm{~N}_{2} \mathrm{O}_{2}[\mathrm{M}-\mathrm{H}]^{-}$287.0826, found 287.0820.

3-Isopropyl-4-(thiophen-2-yl)-1H-benzo[g]indazole-7-carboxylic acid (6e). The mixture of 20e (65 mg, $0.12 \mathrm{mmol})$ and DDQ (83 mg, $0.37 \mathrm{mmol})$ in $\mathrm{CH}_{2} \mathrm{Cl}_{2} / \mathrm{H}_{2} \mathrm{O}\left(5 / 1,1.2 \mathrm{~cm}^{3}\right)$ was stirred at rt for $18 \mathrm{~h}$. The resulting mixture was diluted with $\mathrm{CHCl}_{3}$, washed with $\mathrm{H}_{2} \mathrm{O}$, and dried over $\mathrm{Na}_{2} \mathrm{SO}_{4}$. The solvent was removed in vacuo and the residue was chromatographed on silica gel $\left(\mathrm{CHCl}_{3}\right)$ to afford the title compound $21 \mathrm{e}(36.8 \mathrm{mg}, 73 \%)$ as a white solid: $\mathrm{mp} 135-136{ }^{\circ} \mathrm{C}$; IR (neat): $v_{\max } / \mathrm{cm}^{-1}$ 1746, $1714(\mathrm{C}=\mathrm{O}), 1262\left(\mathrm{OCH}_{3}\right) ; \delta_{\mathrm{H}}\left(500 \mathrm{MHz} ; \mathrm{CDCl}_{3} ; \mathrm{Me} 4 \mathrm{Si}\right) 1.21(6 \mathrm{H}, \mathrm{d}, J 6.9 \mathrm{~Hz}), 2.99-3.04$ 
$(1 \mathrm{H}, \mathrm{m}), 4.00(3 \mathrm{H}, \mathrm{s}), 4.20(3 \mathrm{H}, \mathrm{s}), 7.14-7.16(2 \mathrm{H}, \mathrm{m}), 7.45(1 \mathrm{H}, \mathrm{d}, J 4.6 \mathrm{~Hz}), 7.79(1 \mathrm{H}, \mathrm{s}), 8.20(1 \mathrm{H}$, dd, $J$ 8.6, 1.7 Hz), $8.65(1 \mathrm{H}, \mathrm{s})$, and $9.11(1 \mathrm{H}, \mathrm{d}, J 8.6 \mathrm{~Hz}) ; \delta_{\mathrm{C}}\left(125 \mathrm{MHz} ; \mathrm{CDCl}_{3}\right) 22.0(2 \mathrm{C}), 27.1$, $52.3,55.2,123.1,123.5,125.9,126.1,126.3,126.8,126.9,128.0,128.5,130.1,131.1,132.7,138.8$, 139.5, 152.5, 157.8, and 166.7; HRMS (FAB) $m / z$ Calc. for $\mathrm{C}_{22} \mathrm{H}_{21} \mathrm{~N}_{2} \mathrm{O}_{4} \mathrm{~S}\left(\mathrm{MH}^{+}\right)$409.1217, found 409.1215.

The mixture of 21e (30 mg, $0.073 \mathrm{mmol})$ and $3 \mathrm{~N} \mathrm{NaOH}\left(15 \mathrm{~cm}^{3}, 0.44 \mathrm{mmol}\right)$ in 1,4-dioxane was stirred at $40^{\circ} \mathrm{C}$ for $12 \mathrm{~h}$. After addition of $\mathrm{NH}_{4} \mathrm{Cl}(39 \mathrm{mg}, 0.73 \mathrm{mmol})$, the mixture was stirred at rt for $1 \mathrm{~h}$, then concentrated in vacuo. The residue was chromatographed on silica gel $\left(\mathrm{CHCl}_{3} / \mathrm{MeOH}\right.$ $=9 / 1)$ to afford the title compound $6 \mathbf{e}(19.9 \mathrm{mg}, 81 \%)$ as a white solid: $\mathrm{mp}>300{ }^{\circ} \mathrm{C}$; IR (neat): $v_{\max } / \mathrm{cm}^{-1} 1681(\mathrm{C}=\mathrm{O}) ; \delta_{\mathrm{H}}(500 \mathrm{MHz}$; DMSO-d6; Me $4 \mathrm{Si}) 1.15(6 \mathrm{H}, \mathrm{d}, J 6.9 \mathrm{~Hz}), 3.09-3.14$ $(1 \mathrm{H}, \mathrm{m}), 7.23(1 \mathrm{H}, \mathrm{dd}, J 4.9,3.7 \mathrm{~Hz}), 7.31(1 \mathrm{H}, \mathrm{d}, J 3.7 \mathrm{~Hz}), 7.62(1 \mathrm{H}, \mathrm{s}), 7.70(1 \mathrm{H}, \mathrm{d}, J 4.9 \mathrm{~Hz})$, $8.17(1 \mathrm{H}, \mathrm{d}, J 8.6 \mathrm{~Hz}), 8.56(1 \mathrm{H}, \mathrm{d}, J 8.6 \mathrm{~Hz})$, and $8.67(1 \mathrm{H}, \mathrm{s}) ; \delta_{\mathrm{C}}(125 \mathrm{MHz}$; DMSO-d6) $22.7(2 \mathrm{C})$, $26.3,116.0,121.9,122.9,124.0,126.3(2 \mathrm{C}), 127.3,127.45,127.51,128.7,130.4,130.6,138.9,140.3$, 150.3, and 167.3; HRMS (FAB) $m / z$ Calc. for $\mathrm{C}_{19} \mathrm{H}_{15} \mathrm{~N}_{2} \mathrm{O}_{2} \mathrm{~S}[\mathrm{M}-\mathrm{H}]^{-}$335.0860, found 335.0865.

Methyl 3-bromo-4-[3-(dimethylamino)acryloyl]benzoate (24). The mixture of 22 (5.53 g, $21.5 \mathrm{mmol})$ in dimethylformamide dimethylacetal (23) $\left(17.3 \mathrm{~cm}^{3}, 129 \mathrm{mmol}\right)$ was stirred at $85^{\circ} \mathrm{C}$ for $8 \mathrm{~h}$ in an open vessel. After cooled to rt, the reaction mixture was concentrated in vacuo and the residue was recrystallized from EtOAc-Et $2 \mathrm{O}$ to afford the title compound $24(5.77 \mathrm{~g}, 86 \%)$ as yellow crystals: $\mathrm{mp} 102-103{ }^{\circ} \mathrm{C}$; IR (neat): $v_{\max } / \mathrm{cm}^{-1} 1719(\mathrm{C}=\mathrm{O}), 1640(\mathrm{C}=\mathrm{O}) ; \delta_{\mathrm{H}}\left(500 \mathrm{MHz} ; \mathrm{CDCl}_{3}\right.$; $\left.\mathrm{Me}_{4} \mathrm{Si}\right) 2.90(4 \mathrm{H}, \mathrm{s}), 3.11(3 \mathrm{H}, \mathrm{br} \mathrm{s}), 3.93(3 \mathrm{H}, \mathrm{s}), 5.30(1 \mathrm{H}, \mathrm{d}, J 12.6 \mathrm{~Hz}), 6.74(1 \mathrm{H}, \mathrm{br}$ s), $7.40(1 \mathrm{H}$, br s), $7.97(1 \mathrm{H}, \mathrm{dd}, J 8.0,1.7 \mathrm{~Hz})$, and $8.24(1 \mathrm{H}, \mathrm{d}, J 1.7 \mathrm{~Hz}) ; \delta_{\mathrm{C}}\left(125 \mathrm{MHz} ; \mathrm{CDCl}_{3}\right) 37.2,45.1,52.4$, 95.0, 98.7, 128.2, 128.4, 129.3, 131.4, 134.1, 154.1, 157.2, and 165.4. Anal. Found: C, 50.3; H, 4.4; N, 4.5. Calc. for $\mathrm{C}_{13} \mathrm{H}_{14} \mathrm{BrN}_{2} \mathrm{O}_{3}: \mathrm{C}, 50.0 ; \mathrm{H}, 4.5 ; \mathrm{N}, 4.5 \%$.

Methyl 4-(1-benzyl-1H-pyrazol-5-yl)-3-bromobenzoate (26). The mixture of 24 (312 mg, 
$1.0 \mathrm{mmol}), \mathrm{BnNHNH}_{2}(25)\left(0.22 \mathrm{~cm}^{3}, 2.0 \mathrm{mmol}\right)$, and AcONa (205 mg, $\left.2.5 \mathrm{mmol}\right)$ in AcOH (1.0 $\mathrm{cm}^{3}$ ) was stirred at $60{ }^{\circ} \mathrm{C}$ for $5 \mathrm{~h}$. The mixture was diluted with $\mathrm{H}_{2} \mathrm{O}$ and cooled on ice. To the mixture was added $\mathrm{NaOH}$ until the $\mathrm{pH}$ was about 12 , then the resulting mixture was extracted with $\mathrm{Et}_{2} \mathrm{O}$ twice. The combined extracts were washed with $1 \mathrm{~N} \mathrm{HCl}, \mathrm{H}_{2} \mathrm{O}$, and brine, dried over $\mathrm{Na}_{2} \mathrm{SO}_{4}$, and concentrated in vacuo. The residue was chromatographed on silica gel (hexane/EtOAc $=4 / 1)$ to afford the title compound $26(248 \mathrm{mg}, 67 \%)$ as a colourless oil: IR (neat): $v_{\max } / \mathrm{cm}^{-1} 1725(\mathrm{C}=\mathrm{O})$, $1283\left(\mathrm{OCH}_{3}\right) ; \delta_{\mathrm{H}}\left(400 \mathrm{MHz} ; \mathrm{CDCl}_{3} ; \mathrm{Me}_{4} \mathrm{Si}\right) 3.95(3 \mathrm{H}, \mathrm{s}), 5.19(2 \mathrm{H}, \mathrm{s}), 6.35(1 \mathrm{H}, \mathrm{d}, J 1.7 \mathrm{~Hz})$, 6.92-6.94 (2H, m), 7.18-7.21 (4H, m), $7.63(1 \mathrm{H}, \mathrm{d}, J 1.7 \mathrm{~Hz}), 7.92(1 \mathrm{H}, \mathrm{dd}, J 7.9,1.7 \mathrm{~Hz})$, and 8.33 $(1 \mathrm{H}, \mathrm{d}, J 1.7 \mathrm{~Hz}) ; \delta_{\mathrm{C}}\left(125 \mathrm{MHz} ; \mathrm{CDCl}_{3}\right) 52.5,53.8,107.7,124.4,127.1,127.6(2 \mathrm{C}), 128.0,128.4$ (2C), 132.1, 133.8, 133.8, 136.4, 136.5, 138.8, 140.8, and 165.1; HRMS (FAB) $m / z$ Calc. for $\mathrm{C}_{18} \mathrm{H}_{16} \mathrm{BrN}_{2} \mathrm{O}_{2}\left(\mathrm{MH}^{+}\right)$371.0390, found 371.0383.

Methyl 4-(1-benzyl-1H-pyrazol-5-yl)-3-ethynylbenzoate (27). To the mixture of 26 (74 mg, $0.20 \mathrm{mmol}), \mathrm{PdCl}_{2}(\mathrm{PhCN})_{2}(7.7 \mathrm{mg}, 0.020 \mathrm{mmol}), \mathrm{CuI}(3.8 \mathrm{mg}, 0.020 \mathrm{mmol})$ in toluene $\left(0.5 \mathrm{~cm}^{3}\right)$ were added $i$ - $\operatorname{Pr}_{2} \mathrm{NH}\left(0.084 \mathrm{~cm}^{3}, 0.60 \mathrm{mmol}\right)$ and TMS-acetylene $\left(0.055 \mathrm{~cm}^{3}, 0.40 \mathrm{mmol}\right)$, and a solution of $t$-Bu3P in toluene $\left(1.0 \mathrm{M}, 0.040 \mathrm{~cm}^{3}\right)$ under argon atmosphere. After stirring at $20{ }^{\circ} \mathrm{C}$ for $4.5 \mathrm{~h}$, the mixture was diluted with $\mathrm{Et}_{2} \mathrm{O}$. The resulting mixture was washed with $\mathrm{H}_{2} \mathrm{O}$ and brine, dried over $\mathrm{Na}_{2} \mathrm{SO}_{4}$, and concentrated in vacuo. The residue was chromatographed on silica gel $\begin{array}{lllll}\text { (hexane/EtOAc } & = & \text { 4/1) } & \text { to } & \text { afford }\end{array}$ 4-(1-benzyl-1H-pyrazol-5-yl)-3-[(trimethylsilyl)ethynyl]benzoate (73 mg, containing inseparable impurities, $<94 \%$ ) as a yellow oil. This crude product was used for the next reaction without further purifications. $\delta_{\mathrm{H}}\left(400 \mathrm{MHz} ; \mathrm{CDCl}_{3} ; \mathrm{Me}_{4} \mathrm{Si}\right) 0.16(9 \mathrm{H}, \mathrm{s}), 3.94(3 \mathrm{H}, \mathrm{s}), 5.27(2 \mathrm{H}, \mathrm{s}), 6.40(1 \mathrm{H}, \mathrm{d}, J 2.0$ Hz), 6.91-6.93 (2H, m), 7.18-7.24 (4H, m), $7.60(1 \mathrm{H}, \mathrm{d}, J 1.7 \mathrm{~Hz}), 7.92(1 \mathrm{H}, \mathrm{dd}, J$ 8.0, $1.7 \mathrm{~Hz})$, and $8.21(1 \mathrm{H}, \mathrm{d}, J 1.7 \mathrm{~Hz})$.

The coupling product $(73 \mathrm{mg})$ was dissolved in $\mathrm{MeOH}\left(2.0 \mathrm{~cm}^{3}\right)$. After addition of $\mathrm{K}_{2} \mathrm{CO}_{3}(52$ $\mathrm{mg}, 0.38 \mathrm{mmol}$ ), the mixture was stirred at $\mathrm{rt}$ for $1 \mathrm{~h}$, then diluted with $\mathrm{H}_{2} \mathrm{O}$ and extracted with 
EtOAc. The extract was washed with brine, dried over $\mathrm{Na}_{2} \mathrm{SO}_{4}$, and concentrated in vacuo. The residue was chromatographed on silica gel (hexane/EtOAc $=4 / 1$ to $2 / 3$ ) to afford the title compound $27(29.1 \mathrm{mg}, 46 \%)$ as a yellow oil: IR (neat): $\nu_{\max } / \mathrm{cm}^{-1} 3289(\mathrm{C} \equiv \mathrm{CH}), 1726(\mathrm{C}=\mathrm{O}), 1295\left(\mathrm{OCH}_{3}\right) ; \delta_{\mathrm{H}}$ (400 MHz; CDCl 3 ; Me4Si) $3.13(1 \mathrm{H}, \mathrm{s}), 3.94(3 \mathrm{H}, \mathrm{s}), 5.28(2 \mathrm{H}, \mathrm{s}), 6.42(1 \mathrm{H}, \mathrm{d}, J 2.0 \mathrm{~Hz}), 6.92-6.94$ $(2 \mathrm{H}, \mathrm{m}), 7.18-7.26(4 \mathrm{H}, \mathrm{m}), 7.62(1 \mathrm{H}, \mathrm{d}, J 2.0 \mathrm{~Hz}), 7.96(1 \mathrm{H}, \mathrm{dd}, J 8.0,2.0 \mathrm{~Hz})$, and $8.26(1 \mathrm{H}, \mathrm{d}, J$ $1.7 \mathrm{~Hz}) ; \delta_{\mathrm{C}}\left(100 \mathrm{MHz} ; \mathrm{CDCl}_{3}\right) 52.4,53.9,80.7,82.1,107.9,122.9,127.1(2 \mathrm{C}), 127.5,128.5(2 \mathrm{C})$, $129.5,130.6,130.7,134.4,137.0,137.8,139.0,140.7$, and 165.7; HRMS (FAB) $m / z$ Calc. for $\mathrm{C}_{20} \mathrm{H}_{17} \mathrm{~N}_{2} \mathrm{O}_{2}\left(\mathrm{MH}^{+}\right)$317.1285, found 317.1290.

Methyl 1-benzyl-1H-benzo[g]indazole-7-carboxylate (21g). Under argon atmosphere, the mixture of 27 (29 mg, 0,092 mmol), $\operatorname{IPrAuCl}(2.9 \mathrm{mg}, 4.6 \mu \mathrm{mol})$, and AgNTf 2 (1.8 mg, $4.6 \mu \mathrm{mol})$ in xylene was stirred at $130{ }^{\circ} \mathrm{C}$ for $4 \mathrm{~h}$. The resulting mixture was filtered and concentrated in vacuo. The residue was chromatographed on silica gel (hexane/EtOAc $=4 / 1)$ to afford the title compound $21 \mathrm{~g}(11.0 \mathrm{mg}, 38 \%)$ as a white solid: $\mathrm{mp} 163-164{ }^{\circ} \mathrm{C}$; IR (neat): $v_{\max } / \mathrm{cm}^{-1} 1715(\mathrm{C}=\mathrm{O}), 1284$ $\left(\mathrm{OCH}_{3}\right) ; \delta_{\mathrm{H}}\left(500 \mathrm{MHz} ; \mathrm{CDCl}_{3} ; \mathrm{Me}_{4} \mathrm{Si}\right) 3.96(3 \mathrm{H}, \mathrm{s}), 6.11(2 \mathrm{H}, \mathrm{s}), 7.09(2 \mathrm{H}, \mathrm{d}, J 7.4 \mathrm{~Hz}), 7.23-7.30$ $(3 \mathrm{H}, \mathrm{m}), 7.60(1 \mathrm{H}, \mathrm{d}, J 9.2 \mathrm{~Hz}), 7.78(1 \mathrm{H}, \mathrm{d}, J 9.2 \mathrm{~Hz}), 8.05(1 \mathrm{H}, \mathrm{dd}, J 8.6,1.7 \mathrm{~Hz}), 8.18(1 \mathrm{H}, \mathrm{s})$ $8.20(1 \mathrm{H}, \mathrm{s})$, and $8.65(1 \mathrm{H}, \mathrm{d}, J 1.7 \mathrm{~Hz}) ; \delta_{\mathrm{C}}\left(125 \mathrm{MHz} ; \mathrm{CDCl}_{3}\right) 52.2,56.3,120.2,122.1,123.1,123.6$, 125.8, 126.1, 127.2, 128.8, 131.4, 131.5, 132.6, 133.9 (2C), $134.2(2 \mathrm{C}), 135.3,136.6$, and 166.9; HRMS (FAB) $m / z$ Calc. for $\mathrm{C}_{20} \mathrm{H}_{17} \mathrm{~N}_{2} \mathrm{O}_{2}\left(\mathrm{MH}^{+}\right) 317.1285$, found 317.1290 .

1H-Benzo[g]indazole-7-carboxylic acid (6g). Under oxygen atmosphere, $21 \mathrm{~g}$ (11 mg, 0.035 mmol) and DMSO $\left(0.025 \mathrm{~cm}^{3}, 0.35 \mathrm{mmol}\right)$ were dissolved in THF $\left(0.35 \mathrm{~cm}^{3}\right)$ and the mixture was cooled to $0{ }^{\circ} \mathrm{C}$. To the mixture was added $t$-BuOK $(27 \mathrm{mg}, 0.24 \mathrm{mmol})$ and the resulting mixture was stirred for $15 \mathrm{~min}$. After addition of $\mathrm{H}_{2} \mathrm{O}\left(0.1 \mathrm{~cm}^{3}\right)$, the mixture was stirred at $0{ }^{\circ} \mathrm{C}$ for $0.5 \mathrm{~h}$ and at $\mathrm{rt}$ for $0.5 \mathrm{~h}$. The mixture was diluted with $\mathrm{H}_{2} \mathrm{O}\left(c a .0 .5 \mathrm{~cm}^{3}\right)$ and $\mathrm{NH}_{4} \mathrm{Cl}(28 \mathrm{mg}, 0.52 \mathrm{mmol})$ was added to it. After stirring at $\mathrm{rt}$ for $1 \mathrm{~h}$, the mixture was freeze dried and the residue was purified by reverse 
phase HPLC [3-6\% MeCN in $\mathrm{H}_{2} \mathrm{O}$ (containing $0.1 \% \mathrm{NH}_{3}$ ); flow rate: $10 \mathrm{~cm}^{3} \mathrm{~min}^{-1}$ ] to afford the title compound $\mathbf{6 g}$ as an $\mathrm{NH}_{3}$ salt $(3.3 \mathrm{mg}, 41 \%)$. White solid: $\mathrm{mp}>300{ }^{\circ} \mathrm{C}$; IR (neat): $v_{\max } / \mathrm{cm}^{-1} 1689$ $(\mathrm{C}=\mathrm{O}) ; \delta_{\mathrm{H}}\left(400 \mathrm{MHz}\right.$; DMSO- $\left.d_{6} ; \mathrm{Me}_{4} \mathrm{Si}\right) 7.60(1 \mathrm{H}, \mathrm{d}, J 8.6 \mathrm{~Hz}), 7.76(1 \mathrm{H}, \mathrm{d}, J 8.6 \mathrm{~Hz}), 8.14(1 \mathrm{H}, \mathrm{d}$, $J 8.6 \mathrm{~Hz}), 8.17(1 \mathrm{H}, \mathrm{s}), 8.44(1 \mathrm{H}, \mathrm{d}, J 8.6 \mathrm{~Hz})$, and $8.57(1 \mathrm{H}, \mathrm{s}) ; \delta \mathrm{c}(125 \mathrm{MHz}$; DMSO-d6) 119.5, $119.7,121.4,122.3,123.0,126.6,129.9,130.6,131.1,132.8,133.9$, and 168.0; HRMS (FAB) $m / z$ Calc. for $\mathrm{C}_{12} \mathrm{H}_{7} \mathrm{~N}_{2} \mathrm{O}_{2}[\mathrm{M}-\mathrm{H}]^{-} 211.0513$, found 211.0523 .

\section{Molecular modeling study of CK2 $\alpha$ complexes with benzo[g]indazole 6a, 6f, and $6 \mathrm{~g}$}

Complex structures of CK2 $\alpha$ with $\mathbf{6 a}, \mathbf{6 f}$, and $\mathbf{6 g}$ were modeled manually based on the crystal structure of CK2 $\alpha$ with 3a using MOE. Each model was subjected to energy minimization applying the MMFF force field, and then the binding affinity was estimated by the MM/GBVI method.

\section{CK2 kinase assay}

$\mathrm{CK} 2 \alpha$ or CK2 $\alpha^{\prime}$ kinase reaction was done in a reaction buffer $\left[0.015 \mathrm{~cm}^{3} ; 20 \mathrm{mM}\right.$ MOPS pH 7.2, $25 \mathrm{mM} \beta$-glycerol phosphate, $5 \mathrm{mM}$ EGTA, $1 \mathrm{mM}$ sodium orthovanadate, $13.5 \mathrm{mM} \mathrm{MgCl}, 0.4$ $\mu \mathrm{M}$ PKA inhibitor cocktail, $0.2 \mathrm{mM}$ CK2 substrate peptide (RRRDDDSDDD), $8.5 \mathrm{mU}$ CK2 $\alpha$ enzyme, $90 \mu \mathrm{M}$ ATP, $2.2 \mathrm{nM}\left[\gamma_{-}{ }^{32} \mathrm{P}\right]$ ATP $]$. After incubation at $37{ }^{\circ} \mathrm{C}$ for $10 \mathrm{~min}$, the reaction was terminated by the addition of $0.010 \mathrm{~cm}^{3}$ of $40 \%$ TCA. $0.005 \mathrm{~cm}^{3}$ of the solution was transferred onto a 96-well P81 UniFilter (Whatman), and each well was washed with $0.20 \mathrm{~cm}^{3}$ of $0.75 \%$ phosphoric acid solution 20 times. Residual radioactivity was measured using TOP count NXT (PerkinElmer) after 30-min incubation in $0.020 \mathrm{~cm}^{3}$ of Microscinti-0 (PerkinElmer).

\section{Growth inhibition assay}

HCT-116 cells were cultured in McCoy's 5A medium (GIBCO), supplemented with 10\% (v/v) FBS at $37{ }^{\circ} \mathrm{C}$ in a $5 \% \mathrm{CO}_{2}$ incubator. Growth inhibition assays using $\mathrm{HCT}-116$ cells were performed in 96-well plates (BD Falcon). HCT-116 cells were seeded at 5000 cells/well in $0.050 \mathrm{~cm}^{3}$ of culture 
media and placed for $6 \mathrm{hr}$. Chemicals in DMSO were diluted 200-fold with the culture medium in advance. Following the addition of $0.040 \mathrm{~cm}^{3}$ of the fresh culture medium, $0.030 \mathrm{~cm}^{3}$ of the chemical diluents were also added to the cell cultures. The final volume of DMSO in the medium was equal to $0.125 \%(\mathrm{v} / \mathrm{v})$. The cells under chemical treatment were incubated for a further $72 \mathrm{hr}$. The wells in the plates were washed twice with Phenol-red minus medium [McCoy's 5A medium (Thermo Scientific)]. After 1 hour incubation with $0.10 \mathrm{~cm}^{3}$ of the medium, the cell culture in each well was supplemented with $0.020 \mathrm{~cm}^{3}$ of the MTS reagent (Promega), followed by incubation for an additional $40 \mathrm{~min}$. Absorbance at $490 \mathrm{~nm}$ of each well was measured using a Wallac 1420 ARVO SX multilabel counter (Perkin Elmer).

\section{Acknowledgements}

This work was supported by Fundamental Studies in Health Sciences of the National Institute of Biomedical Innovation (NIBIO), and Grants-in-Aid for Scientific Research and Platform for Drug Design, Discovery and Development from the MEXT, Japan. Y.S. and Z.H. are supported by a JSPS Research Fellowship for Young Scientists, and by the Kobayashi International Scholarship Foundation, respectively.

\section{References and notes}

1. J. S. Duncan and D. W. Litchfield, Biochim. Biophys. Acta, 2008, 1784, 33-47.

2. (a) J. W. Critchfield, J. E. Coligan, T. M. Folks and S. T. Butera, Proc. Natl. Acad. Sci. U.S.A., 1997, 94, 6110-6115; (b) H. L. Yim, Y. H. Lee, C. H. Lee and S. K. Lee, Planta Med., 1999, 65, 9-13; (c) E. Vangrevelinghe, K. Zimmermann, J. Schoepfer, R. Portmann, D. Fabbro and P. Furet, J. Med. Chem., 2003, 46, 2656-2662; (d) Z. Nie, C. Perretta, P. Erickson, S. Margosiak, R. Almassy, J. Lu, A. Averill, K. M. Yager and S. Chu, Bioorg. Med. Chem. Lett., 2007, 17, 4191-4195; (e) A. Chilin, R. Battistutta, A. Bortolato, G. Cozza, S. Zanatta, G. Poletto, M. Mazzorana, G. Zagotto, E. Uriarte, A. Guiotto, L. A. Pinna, F. Meggio and S. Moro, J. Med. 
Chem., 2008, 51, 752-759.

3. F. J. Lozeman, D. W. Litchfield, C. Pienning, K. Takio, K. A. Walsh and E. D. Krebs, Biochemistry, 1990, 29, 8436-8447.

4. (a) F. Pierre, P. C. Chua, S. E. O’Brien, A. Siddiqui-Jain, P. Bourbon, M. Haddach, J. Michaux, J. Nagasawa, M. K. Schwaebe, E. Stefan, A. Vialettes, J. P. Whitten, K. T. Chen, L. Darjania, R. Stansfield, K. Anderes, J. Bliesath, D. Drygin, C. Ho, M. Omori, C. Proffitt, N. Streiner, K. Trent, W. G. Rice and D. M. Ryckman, J. Med. Chem., 2011, 54, 635-654; (b) R. Battistutta, G. Cozza, F. Pierre, E. Papinutto, G. Lolli, S. Sarno, S. E. O’Brien, A. Siddiqui-Jain, M. Haddach, K. Anderes, D. M. Ryckman, F. Meggio and L. A. Pinna, Biochemistry, 2011, 50, 8478-8488.

5. (a) Y. Suzuki, J. Cluzeau, T. Hara, A. Hirasawa, G. Tsujimoto, S. Oishi, H. Ohno and N. Fujii, Arch. Pharm., 2008, 341, 554-561; for the initial report of pyrazine-based CK2 inhibitors, see: (b) N. Fuchi, Y. Iura, H. Kaneko, M. Yamada and Y. Sekitani, Jpn. Pat., 145786, 2007.

6. (a) T. Nakaniwa, T. Kinoshita, Y. Sekiguchi, T. Tada, I. Nakanishi, K. Kitaura, Y. Suzuki, H. Ohno, A. Hirasawa and G. Tsujimoto, Acta Crystallogr. Sect. F, 2009, 65, 75-79; (b) T. Kinoshita, Y. Sekiguchi, H. Fukada, T. Nakaniwa, T. Tada, S. Nakamura, K. Kitaura, H. Ohno, Y. Suzuki, A. Hirasawa, I. Nakanishi and G. Tsujimoto, Mol. Cell. Biochem., 2011, 356, $97-105$.

7. Z. Hou, I. Nakanishi, T. Kinoshita, M. Yasue, R. Misu, Y. Suzuki, S. Nakamura, T. Kure, H. Ohno, K. Murata, K. Kitaura, A. Hirasawa, G. Tsujimoto, S. Oishi and N. Fujii, J. Med. Chem., 2012, 55, 2899-2903.

8. Lopez et al. have determined the tautomeric structure of various pyrazoles and indazoles by ${ }^{13} \mathrm{C}$ NMR analysis, see: C. Lopez, R. M. Claramunt, A. Trofimenko and J. Elguero, Can. J. Chem., 1993, 71, 678-684.

9. (a) Y. Suzuki, Y. Ohta, S. Oishi, N. Fujii and H. Ohno, J. Org. Chem., 2009, 74, 4246-4251; (b) Y. Suzuki, S. Naoe, S. Oishi, N. Fujii and H. Ohno, Org. Lett., 2012, 14, 326-329.

10. J. C. Antilla, J. M. Baskin, T. E. Barder and S. L. Buchwald, J. Org. Chem., 2004, 69, 
$5578-5587$.

11. T. Hundertmark, A. F. Littke, S. L. Buchwald and G. C. Fu, Org. Lett., 2000, 2, 1729-1731.

12. A. A. Haddach, A. Kelleman and M. V. Deaton-Rewolinski, Tetrahedron Lett., 2002, 43, $399-402$.

13. R. Joyeau, L. D. S. Yadav and M. Wakselman, J. Chem. Soc., Perkin Trans. 1, 1987, 1899-1907.

14. K. Knepper, S. Vanderheiden and S. Bräse, Eur. J. Org. Chem., 2006, 1886-1898.

15. J. García-Fortanet, S. L. Buchwald, Angew. Chem., Int. Ed., 2008, 47, 8108-8111.

16. T. Kawase, A. Konishi, Y. Hirao, K. Matsumoto, H. Kurata and T. Kubo, Chem. Eur. J., 2009, 15, 2653-2661.

17. R. Wu, J. S. Schumm, D. L. Pearson and J. M. Tour, J. Org. Chem., 1996, 61, 6906-6921. 


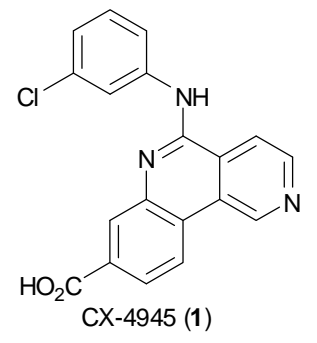<smiles>[R]Nc1nnc(-c2ccc(C(=O)O)cc2)s1</smiles>

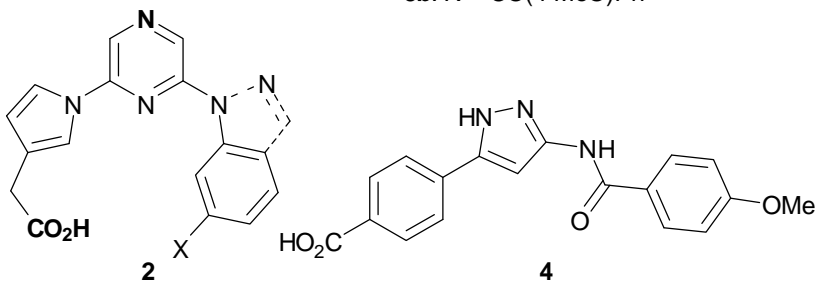

Figure 1. Structures of reported CK2 inhibitors

(A)

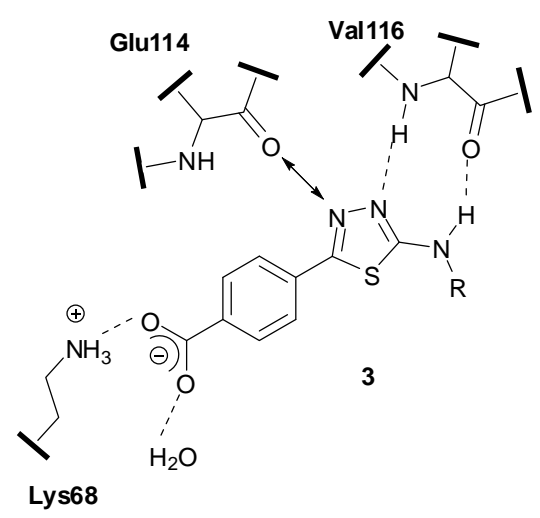

(B)

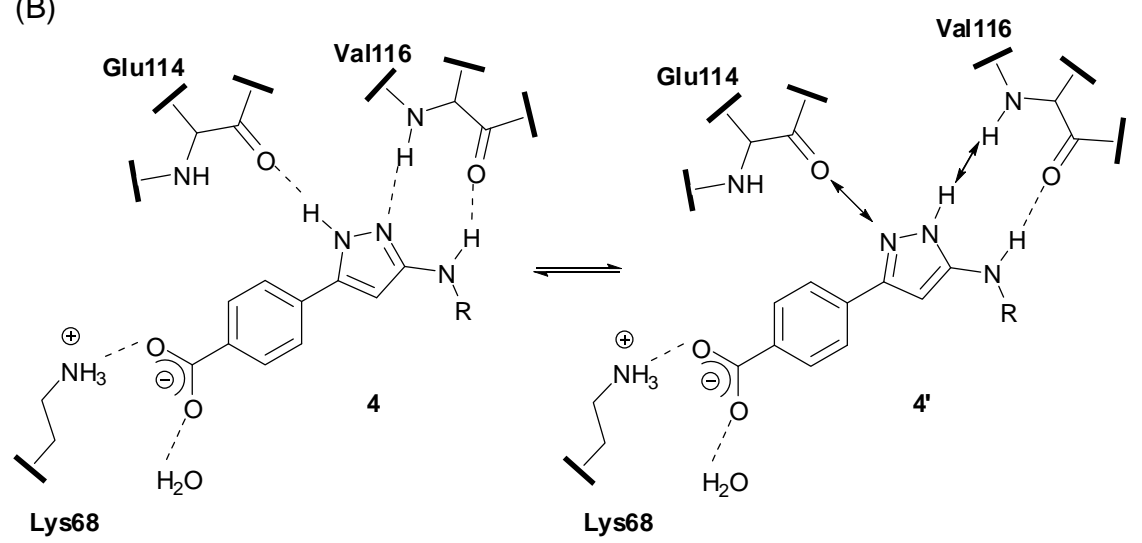

Figure 2. Plausible binding mode of thiadiazole $3(\mathrm{~A})$ and pyrazole 4 (B) with $\mathrm{CK} 2 \alpha(\mathrm{R}=$ 4-methoxybenzoyl) 

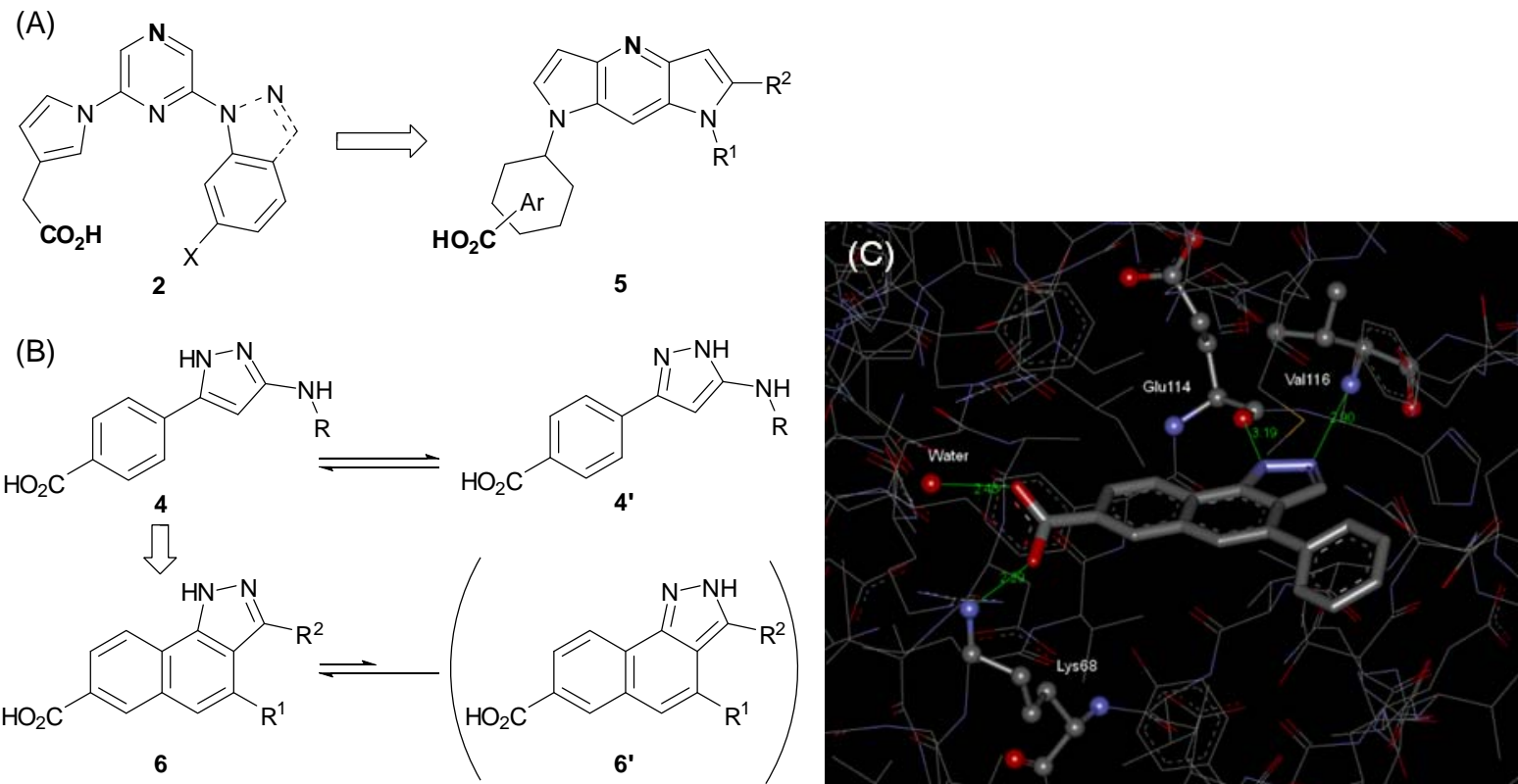

Figure 3. (A) Pyrazine-based CK2 inhibitors 2 and dipyrrolo[3,2-b:2',3'-e]pyridines 5; (B) pyrazole-based CK2 inhibitor 4, benzo[g]indazoles 6, and their tautomers 4' and 6'; and (C) simulated binding mode of $6 \mathbf{a}$ with $\mathrm{CK} 2 \alpha$.

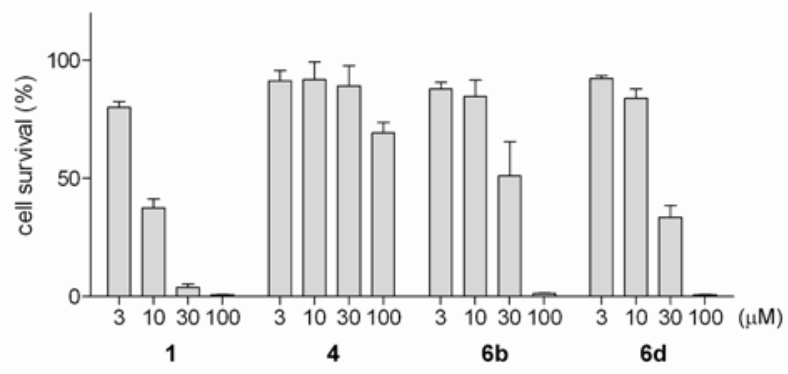

Figure 4. Inhibitory effects on cell proliferation of CK2 inhibitors toward HCT-116 


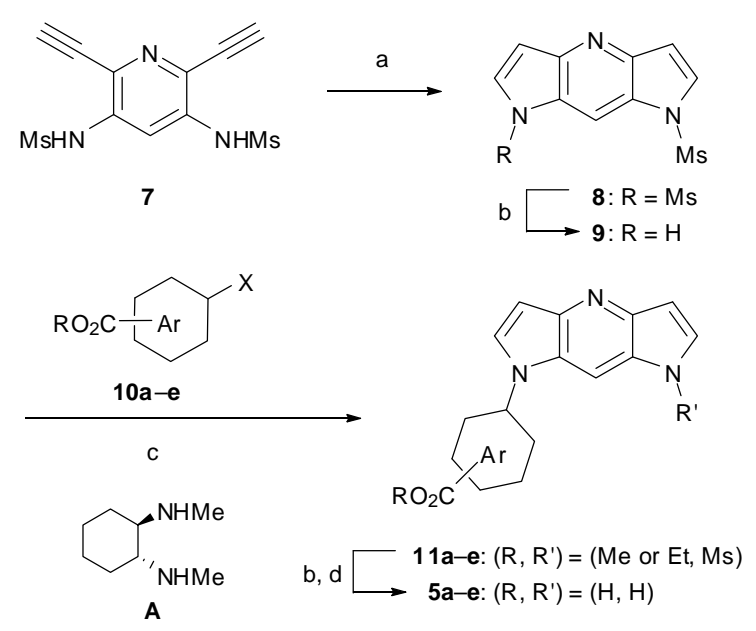

Scheme 1. Synthesis of dipyrrolo[3,2-b:2',3'-e]pyridine derivatives 5a-e. Reagents and conditions: (a) cat. $\mathrm{CuI}, \mathrm{Et}_{3} \mathrm{~N}, 1,4$-dioxane, $60{ }^{\circ} \mathrm{C}, 5 \mathrm{~min}$; (b) $\mathrm{Cs}_{2} \mathrm{CO}_{3}, \mathrm{MeOH} / \mathrm{THF}, \mathrm{rt}, 12 \mathrm{~h}$; (c) cat. $\mathrm{CuI} /( \pm)-\mathrm{A}$, $\mathrm{K}_{3} \mathrm{PO}_{4}$, 1,4-dioxane, reflux; (d) 3N NaOH, THF, rt, 40 h.

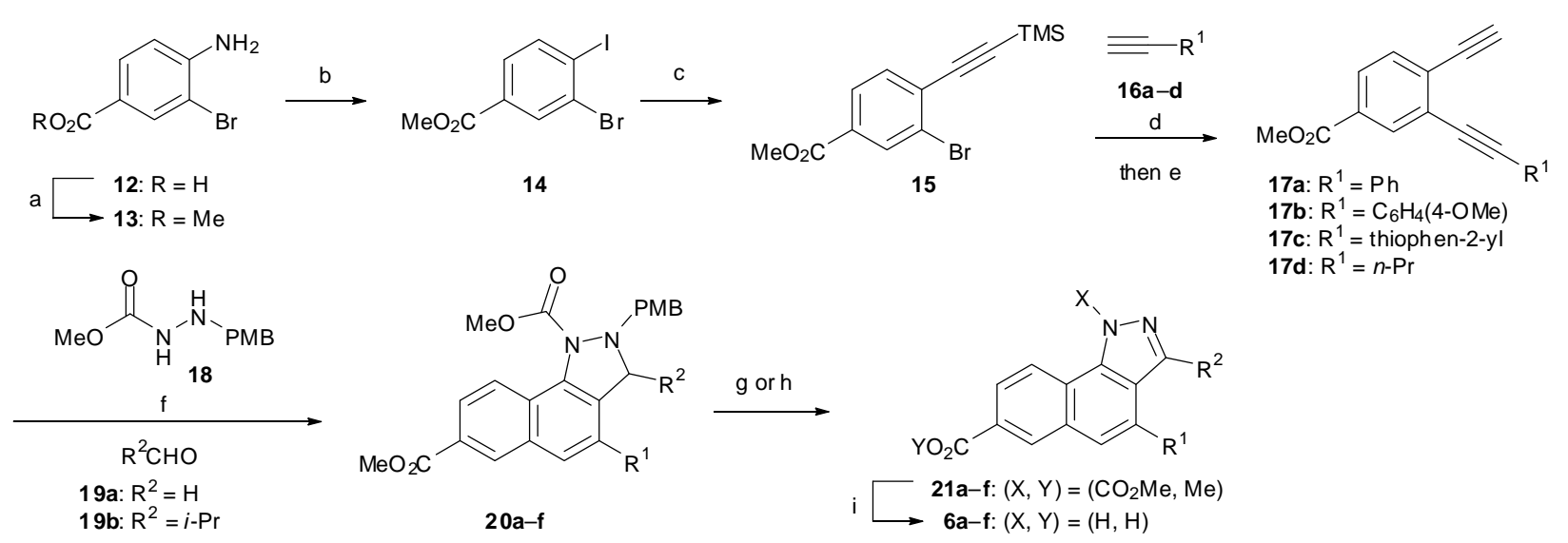

Scheme 2. Synthesis of benzo[g]indazole derivatives $6 \mathbf{a}-\mathbf{f}$ via three-component annulation and cyclization cascade. Reagents and conditions: (a) $\mathrm{H}_{2} \mathrm{SO}_{4}, \mathrm{MeOH}$, reflux, 20 h; (b) $\mathrm{NaNO}_{2}, \mathrm{HCl}_{2} \mathrm{H}_{2} \mathrm{O}$, $0{ }^{\circ} \mathrm{C}, 1 \mathrm{~h}$, then KI, rt, $24 \mathrm{~h}$; (c) TMS-acetylene, cat. $\mathrm{PdCl}_{2}\left(\mathrm{PPh}_{3}\right)_{2} / \mathrm{CuI}_{1} \mathrm{Et}{ }_{3} \mathrm{~N}, \mathrm{THF}, \mathrm{rt}, 1.5 \mathrm{~h}$; (d) cat. $\mathrm{PdCl}_{2}(\mathrm{PhCN})_{2} / t-\mathrm{Bu}_{3} \mathrm{P} / \mathrm{CuI}, i$ - $\mathrm{Pr}_{2} \mathrm{NH}$, toluene, rt; (e) $\mathrm{K}_{2} \mathrm{CO}_{3}, \mathrm{MeOH}, \mathrm{rt}, 1$ h; (f) cat. IPrAuCl/AgOTf, AcOH, 35-80 ${ }^{\circ} \mathrm{C}$; (g) anisole, TFA, $80{ }^{\circ} \mathrm{C}$ (for 21a, 21b, 21d and 21f); (h) DDQ, $\mathrm{CH}_{2} \mathrm{Cl}_{2} / \mathrm{H}_{2} \mathrm{O}$, rt (for 21c and 21e); (i) $3 \mathrm{~N} \mathrm{NaOH}, 1,4$-dioxane, $40{ }^{\circ} \mathrm{C}$. 


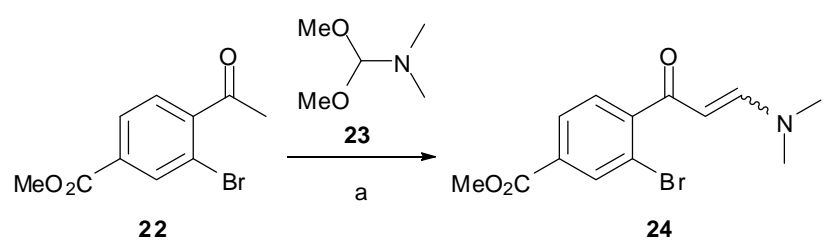

22

24

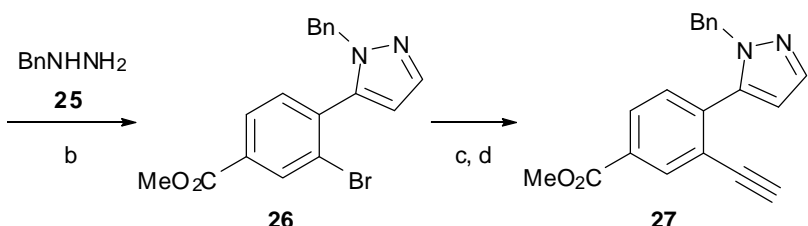

26

27

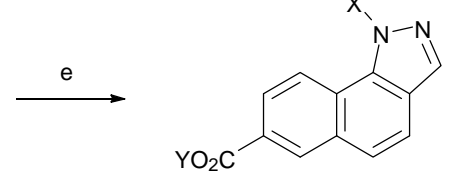

21g: $(X, Y)=(B n, M e)$

Scheme 3. Synthesis of benzo[g]indazole derivative 6 g. Reagents and conditions: (a) $85{ }^{\circ} \mathrm{C}, 8 \mathrm{~h}$; (b) AcONa, AcOH, $60{ }^{\circ} \mathrm{C}, 5$ h; (c) TMS-acetylene, cat. $\mathrm{PdCl}_{2}\left(\mathrm{PPh}_{3}\right)_{2} / \mathrm{CuI}, \mathrm{Et}_{3} \mathrm{~N}, \mathrm{THF}, \mathrm{rt}, 4.5 \mathrm{~h}$; (d) $\mathrm{K}_{2} \mathrm{CO}_{3}, \mathrm{MeOH}, \mathrm{rt}, 1 \mathrm{~h}$; (e) cat. IPrAuCl/AgNTf , xylene, $130{ }^{\circ} \mathrm{C}$; (f) $t$-BuOK, DMSO, THF/H $\mathrm{H}_{2} \mathrm{O}, \mathrm{O}_{2}$, $\mathrm{rt}, 0.5 \mathrm{~h}$. 
Table 1. Structures of the synthesized heterocyclic compounds and the CK2 inhibitory activities

5c

${ }^{a}$ Less than $20 \%$ inhibition was observed in the presence of $32 \mu \mathrm{M}$ of compounds. 